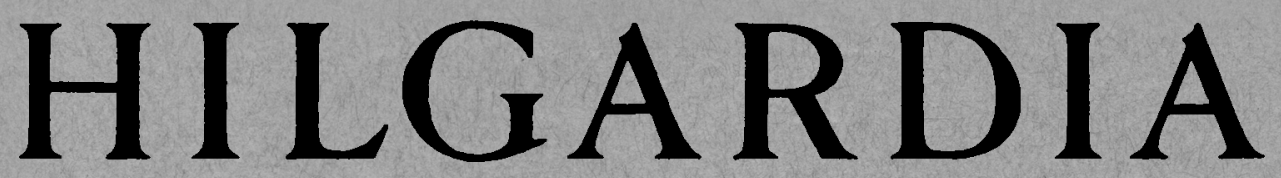

A Journal of Agricultural Science Published by the California Agricultural Experiment Station

\title{
EXPERIMENTS ON SETTING FRUIT WITH GROWTH-REGULATING SUBSTANCES ON FIELD-GROWN TOMATOES IN CALIFORNIA
}

LOUIS K. MANN and P. A. MINGES

UNIVERSITY OF CALIFORNIA · BERKELEY, CALIFORNIA 


\section{CONTENTS}

Introduction . . . . . . . . . . . . . . . . . . . . . . 309

Materials and methods . . . . . . . . . . . . . . . . . 310

Results . . . . . . . . . . . . . . . . . . . . . . . 313

Effectiveness of growth substances . . . . . . . . . . . . 313

Aerosols and dusts compared with water sprays . . . . . . . . 313

Concentration of growth substances . . . . . . . . . . . . 315

Plant injury caused by growth-substance treatments . . . . . . 318

Growth substances and fruit size . . . . . . . . . . . . . 319

Growth substances and fruit quality . . . . . . . . . . . . . 323

Age of flowers treated and fruit-set . . . . . . . . . . . . . . 324

Number of flowers treated per plant and fruit-set . . . . . . . 325

Use of growth substances on canning tomatoes . . . . . . . . . 326

Yield patterns following growth-substance treatments . . . . . . 326

Summary and conclusions . . . . . . . . . . . . . . . . . . . . 334

Acknowledgments . . . . . . . . . . . . . . . . . . . . . . . . 335

Literature cited . . . . . . . . . . . . . . . . . . . . . 336 


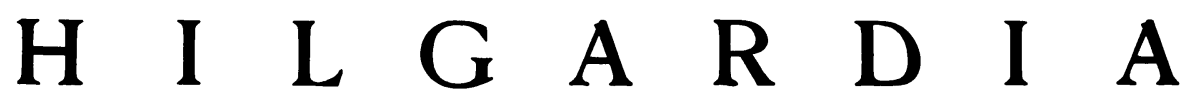

A Journal of Agricultural Science Published by

the California Agricultural Experiment Station

VoL. 19

DECEMBER, 1949

No. 10

\section{EXPERIMENTS ON SETTING FRUIT WITH GROWTH- REGULATING SUBSTANCES ON FIELD-GROWN TOMATOES IN CALIFORNIA ${ }^{1}$}

\author{
LOUIS K. MANN ${ }^{2}$ and P. A. MINGES ${ }^{3}$
}

\section{INTRODUCTION}

The FaILURe of tomatoes to set fruit on the early flower clusters is a common complaint of California growers who produce for the spring and summer market. Poor fruit-set is usually ascribed to low temperatures. Went (1944) has suggested that night temperatures in particular have an important influence on fruit-set.

In each spring-market area, after the danger of winter frost, there follows a period of 6 weeks to 3 months when day temperatures are conducive to good vegetative growth, but night temperatures may drop too low for proper setting. The cool period in the Imperial and Coachella valleys occurs in late February and early March, but by late March night temperatures usually are satisfactory. In the Tulare district, night temperatures may run too low during early and mid-April, but normally no trouble in setting is experienced after May first. In the coastal districts, which are influenced by cool breezes from the ocean, low night temperatures may occur well into June; in the San Francisco Bay district they occur even into July. In each district the earliest fruit generally brings the best market price. Failure of the early clusters to set fruit may mean a delayed harvest period; even, perhaps, a short one because of competition from districts which produce for a later market.

Fruit-set for the canning crop is satisfactory in most years. Early production is less important. Only in the San Francisco Bay district do growers frequently complain of poor fruit-set of this crop.

In the northern United States, where fruit-set on greenhouse tomatoes is poor during the short overcast days of winter, growth-regulating substances have proved effective for increasing yields. In California, where no commercial field tests had been reported, experiments were begun in 1945 to determine if growth substances would increase fruit-set under field conditions. Since that date, some authors in other states have reported negative or inconsistent

\footnotetext{
${ }^{1}$ Received for publication, November 23, 1948.

${ }^{2}$ Assistant Professor of Truck Crops and Assistant Olericulturist in the Experiment Station.

${ }^{3}$ Extension Specialist in Truck Crops.
} 
results (Mitchell, 1947), while others have reported very favorable fruitsetting in the field (Anon., 1948; Wittwer et al., 1948).

A general summary of the 29 tests conducted in 1945-1947, described in this paper, is given in table 1 . The relation of these tests to the early market tomato areas of California-with the approximate periods of planting, early flowering, and start of harvest season-follows :

\begin{tabular}{lllll} 
District & \multicolumn{1}{c}{$\begin{array}{c}\text { Date of } \\
\text { transplanting* }\end{array}$} & \multicolumn{1}{c}{$\begin{array}{c}\text { First } \\
\text { flowering }\end{array}$} & $\begin{array}{c}\text { Start of } \\
\text { market period }\end{array}$ & \multicolumn{1}{c}{$\begin{array}{c}\text { Test number } \\
\text { table 1 }\end{array}$} \\
Imperiai, Coachella & Nov., Dec. & Feb., March & Late April & 3,4 \\
Tulare County.... & February & April & Early June & $15,16,17,18$ \\
South Coast ...... & March & April, May & July & $5,6,7,11,13$ \\
Merced, Madera, & & & Late June or \\
Fresno ........ Late March & Late April, May & early July & $\mathbf{8 , 9 , 1 0}$ \\
San Francisco Bay. & April & Late May, June & Late July & 1,2
\end{tabular}

Experiments in these districts are indicated by the test numbers in table 1. Tests 12,14 , and 25 on canning crops were not made in the early-market districts. Tests 19 to 24 , and 26 to 29 , were, for more convenient observation, conducted near Davis in Yolo County, where early-market tomatoes are a minor crop. Here the plants may be transplanted in late March or early April, and the first flowers appear in early May.

Our objective in these experiments was to determine the possibility of setting fruit under early-market field conditions. This raised the problems, first, of selecting a suitable growth substance from the many substances known to set fruit, and second, of determining the best concentrations and practical methods for field application. In addition, observations had to be made on fruit quality, plant injury, and yield.

\section{MATERIALS AND METHODS}

Materials Used. Growth substances were selected which had been used with considerable success by several workers to set tomato fruit under greenhouse conditions. Too, the chemicals were readily available. These chemicals are:

\section{Chemical name \\ $\beta$-Naphthoxyacetic acid \\ 4-Chlorophenoxyacetic acid \\ Sodium salt of 4-CPA \\ 2,4-Dichlorophenoxyacetic acid}

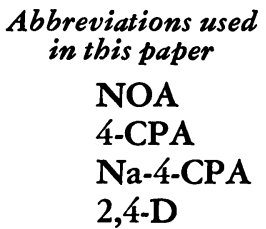

Types of Carriers. The aerosol, water-spray, and dust carriers were tested for applying the chemicals. For aerosols, the growth substance was dissolved in a small quantity of cyclohexanone and mixed with dimethyl ether in small gas cylinders or bombs. For water sprays, concentrated stock solutions were made up in water for the sodium salts and in ethyl alcohol for the acids. These stocks were diluted with water, and the sprays applied with a knapsack-type hand sprayer. No spreaders were used. For dusts, the growth substances were

\footnotetext{
* In Imperial and Coachella valleys the tomatoes are seeded directly in the field in Novem. ber and December.
} 
ground with talc in a ball mill; or talc, wetted with an ethyl alcohol solution of the chemical, was dried and ground. The dusts were shaken on by hand from a cheesecloth bag.

Methods. All tests were coöperatively conducted with growers and county agricultural extension agents. Each grower followed his usual cultural practices of pruning, staking, and irrigating. The number of plants per treatment

TABLE 1

EXPERIMENTS WITH GROWTH-REGULATING SUBSTANCES ON TOMATO PLANTS CLASSIFIED ACCORDING TO TEST NUMBER, GROWER, COUNTY, VARIETY, AND DATE TREATED

(1945-1947)

\begin{tabular}{|c|c|c|c|c|}
\hline Test number & Grower & County 1 & Variety & Date treated \\
\hline 1. & Bernard & Contra Costa & Stone & $6 / 2 / 46$ \\
\hline 2. & Bernard & Contra Costa & Several (mixed lot) & $6 / 14 / 46$ \\
\hline 3.. & $\mathrm{Au}$ & Imperial & Earliana & $2 / 7 / 47$ \\
\hline 4. & Salcedo & Imperial & Earliana & $2 / 13 / 47$ \\
\hline 5 . & Kessler & Los Angeles & Pearson & $4 / 24 / 46$ \\
\hline $6 \ldots$ & Ishibashi & Los Angeles & Earliana & $4 / 18 / 47$ \\
\hline $7 \ldots$ & Teneda & Los Angeles & Earliana & $5 / 7 / 47$ \\
\hline 8. & Cresci & Merced & Pritchard & $4 / 17 / 47$ \\
\hline $9 \ldots$ & Busci & Madera & Pritchard & $4 / 2 / 47$ \\
\hline $10 \ldots \ldots \ldots \ldots \ldots$ & Guido & Madera & Stokesdale & $4 / 25 / 47$ \\
\hline $11 \ldots \ldots \ldots \ldots \ldots \ldots \ldots \ldots \ldots \ldots \ldots$ & Ruoff & Orange & Stone & $4 / 18 / 47$ \\
\hline $12^{*} \ldots \ldots \ldots \ldots \ldots \ldots \ldots \ldots \ldots \ldots$ & Teeters & San Benito & Early Santa Clara & $7 / 31 / 46$ \\
\hline 13. & Wells & San Diego & Pearson & $5 / 13 / 47$ \\
\hline $14^{*}$. & Rowe & Santa Cruz & Pearson & $7 / 12 / 45$ \\
\hline $15 \ldots$ & Allen & Tulare & Earliana & $4 / 22 / 46$ \\
\hline 16. . & Cemo & Tulare & Earliana & $4 / 23 / 46$ \\
\hline 17. & Cemo & Tulare & Pearson & $5 / 1 / 47$ \\
\hline 18. . & Dial & Tulare & Earliana & $4 / 10,4 / 21 / 47$ \\
\hline $19 \ldots \ldots$ & Hansen & Yolo & Earliana & $4 / 19,5 / 10 / 46$ \\
\hline 20,21 . & Hansen & Yolo & Earliana & $5 / 10 / 46$ \\
\hline $22 \ldots \ldots$ & Hansen & Yolo & Earliana & $5 / 10,5 / 21 / 46$ \\
\hline $23 \ldots$ & Hansen & Yolo & Earliana & $5 / 11 / 46$ \\
\hline $24 \ldots \ldots \ldots$ & Hansen & Yolo & Earliana & $5 / 14 / 46$ \\
\hline $25 * \ldots \ldots \ldots$ & Carden & Yolo & Pearson & $7 / 17 / 46$ \\
\hline $26 \ldots \ldots \ldots$ & Tandy & Yolo & Earliana & $4 / 23 / 47$ \\
\hline $27 \ldots$ & Tandy & Yolo & Pearson & $4 / 23 / 47$ \\
\hline $28 \ldots \ldots \ldots$ & Tandy & Yolo & Earliana & $4 / 26 / 47$ \\
\hline $29 \ldots \ldots \ldots \ldots \ldots \ldots \ldots \ldots \ldots \ldots \ldots$ & Tandy & Yolo & Pearson & $4 / 26 / 47$ \\
\hline
\end{tabular}

* These 3 crops grown for cannery; all others used for fresh market.

varied with the grower's field layout and the type of experiment. As indicated in table 1, tests were run in 11 counties. Because of the wide variety of climatic conditions for which information was needed, we attempted to scatter observational or exploratory tests rather than to run a few but wellreplicated experiments. A single test number in table 1 may include several separate experiments if these were started in a given field on the same day. Thus, a test number appearing more than once in any of the tables indicates that 2 or more experiments were run at the given date and place.

The chemicals were applied to the flower clusters without an attempt to treat any specific flower part; however, unless otherwise indicated, we carefully avoided treating foliage. With water sprays, the clusters were thor- 
oughly wetted; with dusts, the clusters were well covered; and with aerosols, each cluster was sprayed for 1 to 2 seconds. Except in a few instances, as noted, plants or flower clusters were treated only once. The control or check plants received no treatment of any kind.

Because of the great variability in the number of flower clusters per vine in different treatments, the amount of growth substance required for a given test was proportional to the number of flower clusters rather than to the field area covered. For this reason the strength of treatment is given as concentration in parts per million-expressed as ppm in this paper-by weight in the carrier, rather than as the amount applied per acre.

TABLE 2

EARLY YIELDS FROM TOMATO PLANTS TREATED WITH WATER SPRAYS OF 4-CPA OR Na-4-CPA*

\begin{tabular}{|c|c|c|}
\hline Stock solution & $\begin{array}{l}\text { Age in days of stock } \\
\text { solution at time of use }\end{array}$ & $\begin{array}{l}\text { Early yield in } \\
\text { pounds per plant }\end{array}$ \\
\hline \multicolumn{3}{|l|}{ Treated } \\
\hline $2.0 \%$ 4-CPA in $95 \%$ ethyl alcohol & 331 & 5.14 \\
\hline $1.12 \% \mathrm{Na}-4-\mathrm{CPA}$ in water........ & 20 & 5.28 \\
\hline $1.0 \%$ 4-CPA in $95 \%$ ethyl alcohol. & 20 & 4.70 \\
\hline 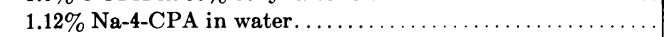 & Fresh & 5.30 \\
\hline $1.0 \% 4-\mathrm{CPA}$ in $95 \%$ ethyl alcohol $\ldots \ldots \ldots \ldots \ldots \ldots \ldots \ldots$ & Fresh & 5.29 \\
\hline Untreated. . & $\ldots$ & 1.13 \\
\hline \multicolumn{2}{|l|}{ Least significant difference at $5 \%$ level. . . . . . . . . . . . . . . } & 1.78 \\
\hline
\end{tabular}

* All at $50 \mathrm{ppm}$, but made up from stock solutions of various ages. Three replicates of 18 to 20 plants in each; Earliana variety. Test 20 of table 1 .

As the project progressed, it became evident that water sprays were effective and, in some ways, more desirable than aerosols or dusts. More of our treatments were therefore applied with this carrier.

For the water-spray treatments fresh stock solutions were almost always used. From a practical standpoint, the stability of stock solutions of 4-CPA and Na-4-CPA is of importance. Data are given in table 2 on the early yields of fruit after treatment with sprays made from stock solutions of various ages. The solutions were stable for the storage periods tested. This agrees with the statement of Zimmerman and Hitchcock. (1944) that "the substituted phenoxy acids are very stable and have been kept as prepared solutions throughout the summer without losing their effectiveness."

Whenever possible, data were obtained on plant injury, fruit count, and early and late yield. Fruits were generally counted 10 days to 3 weeks after treatment. The number of flowers open at the time of treatment was frequently recorded in order to calculate the percentage of flowers set. The flowers were considered open when the calyx and corolla were beginning to separate.

Plots were harvested according to the picking schedule of the grower, although in some instances more regular pickings would have been desirable. Yields were recorded by weight. In many tests, fruits were counted to determine average fruit weight. Culls were sorted out according to the grower's general practice. 
Yield comparisons are usually expressed in actual values rather than as per cent increase over check treatments. Frequently the latter comparisons would be extremely wide and sometimes misleading.

\section{RESULTS}

\section{Effectiveness of Growth Substances}

The 3 chemicals used-4-chlorophenoxyacetic acid, $\beta$-naphthoxyacetic acid, and 2,4-dichlorophenoxyacetic acid-proved effective in setting fruit in the field in most of our tests. Observations and data covering fruit-setting properties of these chemicals and their ability to increase yield are summarized briefly below.

4-Chlorophenoxyacetic acid or its sodium salt in a water spray of $50 \mathrm{ppm}$ was one of the most frequently used and best treatments in our tests. A comparison of the fruit counts from plants so treated with counts from control plants gives a good general picture of its effectiveness. The tests where fruit counts were made 2 to 3 weeks after spraying are shown in figure 1 . The great variability among the tests is not surprising as the tests represent different localities, varieties, times of application, et cetera, as indicated in table 1 . In 16 of the 20 tests, the treatment improved fruit-set. Similar data for a wider range of spray concentrations are given in table 4 . The effectiveness of 4-CPA in increasing yields is indicated by data in table 5 .

$\beta$-Naphthoxyacetic acid applied to Stone (test 1) and Earliana (test 21) varieties as a water spray increased both fruit-set and fruit size. Of the 3 concentrations tried-50, 250, and $500 \mathrm{ppm}$ - the $250 \mathrm{ppm}$ seemed the best and was as satisfactory as the $50 \mathrm{ppm} 4$-CPA spray.

2,4-Dichlorophenoxyacetic acid water sprays were used at concentrations varying from 1 to $25 \mathrm{ppm}$ in tests $15,16,24$, and 26 . In general, sprays containing 10 to 20 ppm 2,4-D gave a set as satisfactory as the $50 \mathrm{ppm} 4$-CPA treatment.

Our observations and data indicate that neither NOA nor 2,4-D has any advantages over 4-CPA. NOA is more expensive and requires higher concentrations; 2,4-D, while effective in very low concentrations, is perhaps more dangerous to use because of the strong formative effects. Our preference for 4-CPA rests on these points and also on its known effectiveness under a wide variety of conditions.

\section{Aerosols and Dusts Compared with Water Sprays}

In our tests, 4-CPA was applied in water sprays, aerosols, and dusts; NOA in water sprays and aerosols; and 2,4-D in water sprays and dusts.

Aerosols were used in several of the early tests, and while growth regulators applied by this method frequently increased both the size of fruit and the number of fruits set, aerosols were, in general, less satisfactory than water sprays. Although the effectiveness of aerosols for field use might be improved, their use was discontinued because this method appeared impractical for field use. In applying aerosols it proved difficult to control drift and to put on definite amounts of the growth regulator. In addition, their preparation is time-consuming and expensive. 

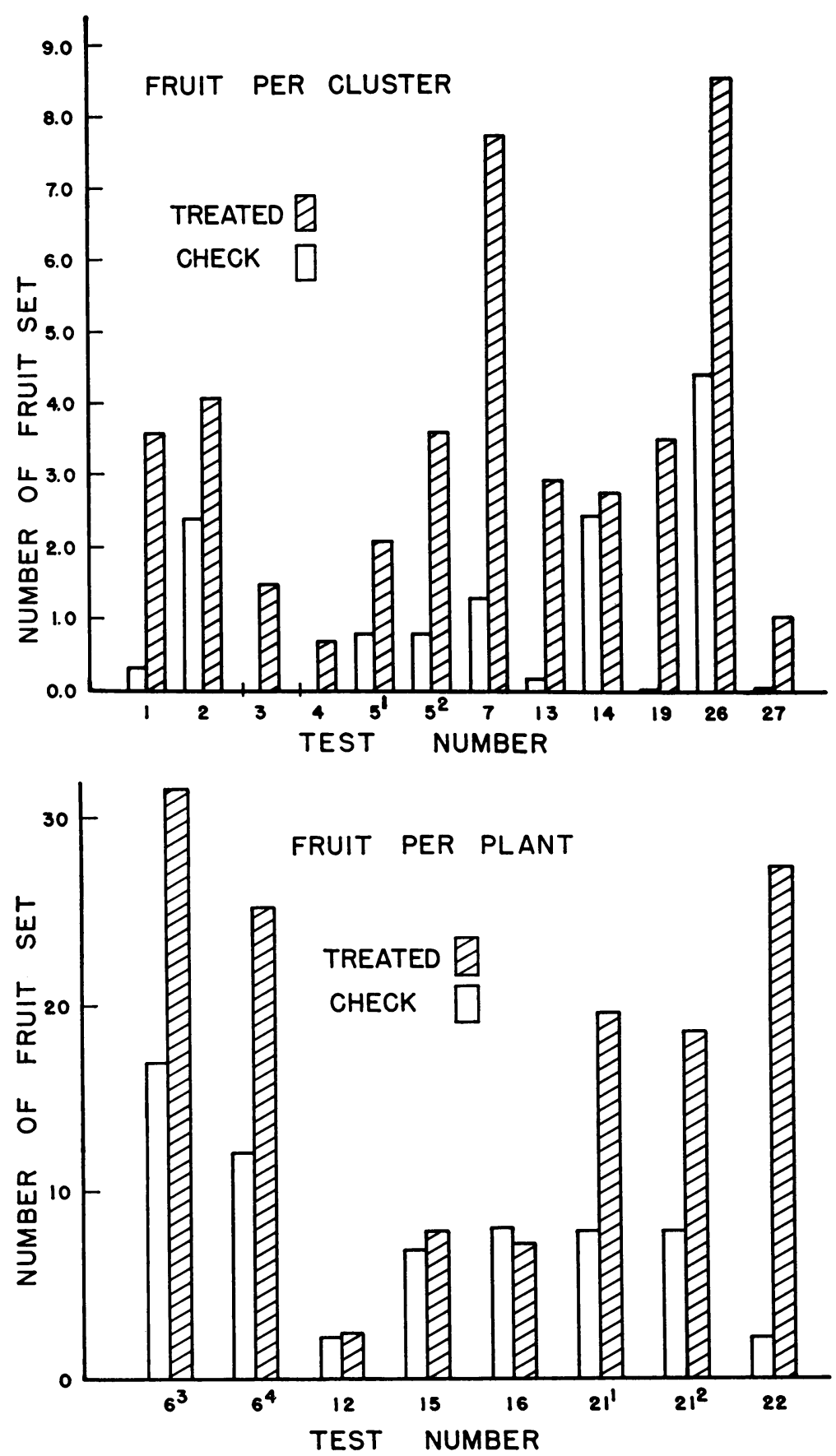

Fig. 1. Top, number of fruits set per cluster or, bottom, per plant, from untreated flowers and from flowers treated with a $50 \mathrm{ppm}$ water spray of 4-chlorophenoxyacetic acid or its sodium salt. (See table 1 for varieties, treatment dates, and localities of the individual tests.)

${ }^{1}$ acid; ${ }^{2}$ salt ; ${ }^{3}$ irrigated plot; ‘ nonirrigated. 
Dusts containing 2,4-D or 4-CPA were applied in 4 tests. The average number of fruits set per cluster by these dust treatments is shown in table 3 . The dusted clusters set much better than the checks, and the highest concentration for each chemical was comparable with the $50 \mathrm{ppm} \mathrm{Na-4-CPA} \mathrm{water} \mathrm{spray.}$

From these data it seems that the chemicals carried in dusts and water sprays might set fruit equally well. However, as we shall point out later, we believe that the growth substances used in these tests must be applied, in so far

TABLE 3

NUMBER OF FRUITS SET AND SIZE OF" FRUITS ON TOMATO PLANTS TREATED WITH 2,4-D AND 4-CPA DUSTS COMPARED WITH AN Na-4-CPA WATER SPRAY, AND WITH UNTREATED PLANTS

\begin{tabular}{|c|c|c|c|c|c|c|}
\hline \multirow{2}{*}{ Treatments } & \multicolumn{6}{|c|}{ Test number, * variety, and number of clusters } \\
\hline & $\begin{array}{c}\text { Test 7 } \\
\text { Earliana } \\
\text { 15 clusters } \\
\begin{array}{c}\text { Average } \\
\text { number } \\
\text { fruits set } \\
\text { per cluster }\end{array}\end{array}$ & \multicolumn{2}{|c|}{$\begin{array}{c}\text { Test } 13 \\
\text { Pearson } \\
22 \text { to } 31 \text { clusters }\end{array}$} & \multicolumn{2}{|c|}{$\begin{array}{c}\text { Test } 28 \\
\text { Earliana } \\
15 \text { clusters }\end{array}$} & $\begin{array}{c}\begin{array}{c}\text { Test } 29 \\
\text { Pearson } \\
20 \text { clusters }\end{array} \\
\begin{array}{c}\text { Average } \\
\text { number } \\
\text { fruits set } \\
\text { per cluster }\end{array}\end{array}$ \\
\hline & & & (lbs.) & & (lbs.) & \\
\hline \multicolumn{7}{|l|}{ Treated } \\
\hline Dusts & & & & & & \\
\hline 4-CPA $200 \mathrm{ppm}$ & $\ldots$ & $\ldots$ & $\ldots$ & 5.7 & 0.25 & 0.15 \\
\hline 4-CPA 500 ppm.... & $\ldots$ & $\ldots$ & $\ldots$ & 6.5 & $\ldots$ & 0.55 \\
\hline 4-CPA 1,000 ppm. $\ldots \ldots \ldots$ & $\ldots$ & $\ldots$ & $\ldots$ & 7.9 & 0.26 & 1.25 \\
\hline \multicolumn{7}{|l|}{ Water spray } \\
\hline Na-4-CPA, 50 ppm......... & 7.7 & 2.9 & 0.33 & 8.5 & 0.24 & 1.1 \\
\hline Untreated $\ldots \ldots \ldots \ldots \ldots \ldots \ldots \ldots$ & 1.3 & 0.2 & 0.13 & 3.4 & 0.19 & 0.0 \\
\hline
\end{tabular}

* See table 1 for varieties, treatment dates, and localities.

as practical, to the flower clusters only. In this respect, dusts, because of their drift, are inferior to water sprays and, thus, like aerosols, are less desirable for field use.

\section{Concentration of Growth Substances}

4-Chlorophenoxyacetic Acid. Several measurements, such as the number of fruits set, yield of fruit, and size of fruit, were used to determine the most effective concentration of growth substances. Data on fruit counts for 4-CPA and Na-4-CPA water sprays are summarized in table 4. In 10 of the 15 tests highest fruit-set was obtained at the $100 \mathrm{ppm}$ concentration. The $250 \mathrm{ppm}$, and especially $1,000 \mathrm{ppm}$ are well beyond the useful range of concentration. In 5 tests $(13,14,16$-acid, 19, and 26$)$ there was no improvement in set with increasing concentrations. In tests 14 and 16-acid, the set following treatment was little or no better than the set in the check. In the other 3 tests all spray treatments were decidedly better than the check and $25 \mathrm{ppm}$ was as effective as the higher concentrations. These tests show that the number of fruits set 


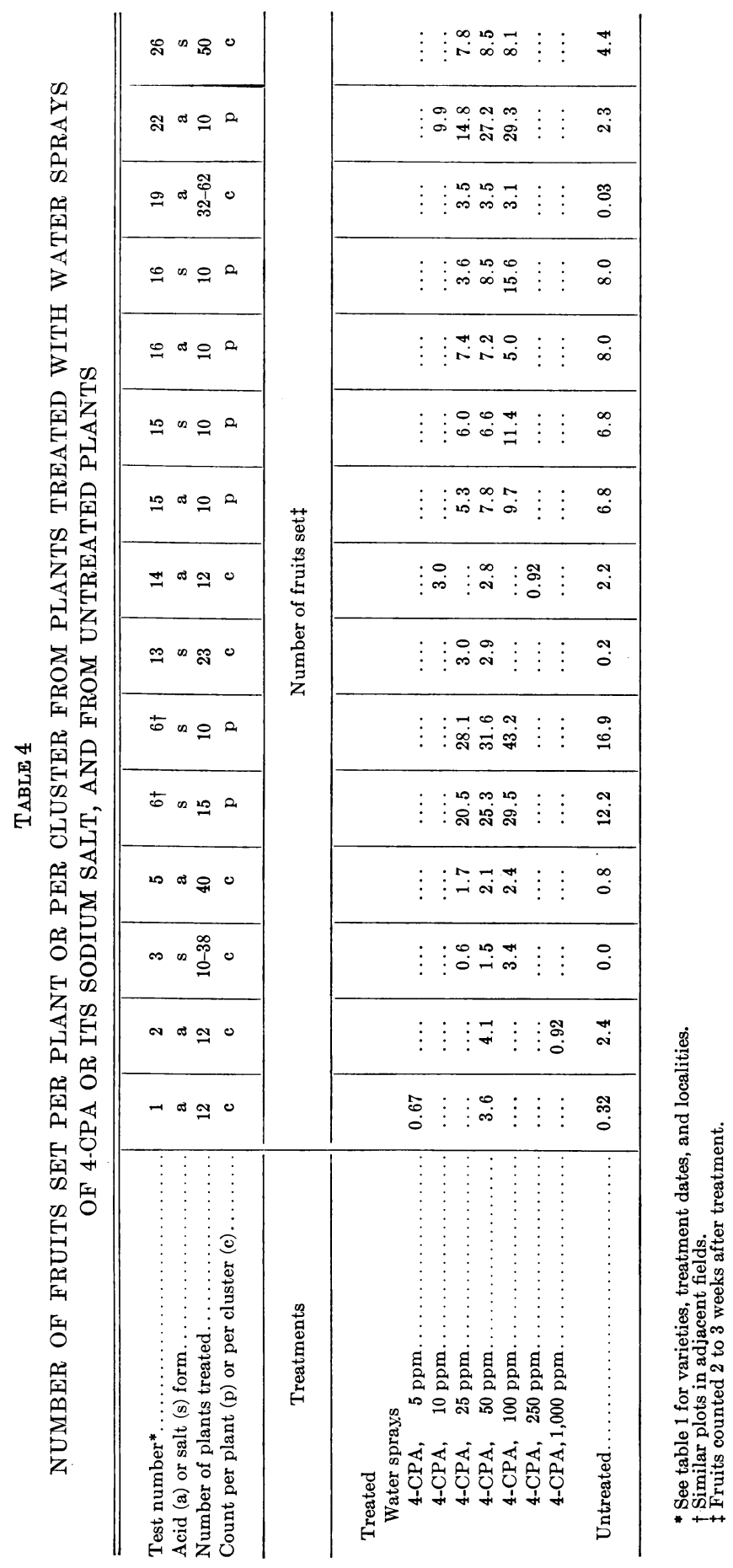


by 4-CPA water sprays generally increases with increasing concentration of the chemical up to $100 \mathrm{ppm}$.

Data on early yield are presented in table 5 and agree well with the data on fruits set. For the 6 tests common to tables 4 and 5 , the early yields correspond closely to the counts of immature fruits. In table 5 only test 25 with a high yield from the check showed little response to spray treatments. These data indicate that with 4-CPA water sprays, yield may be increased by concentrations between 25 and $100 \mathrm{ppm}$.

TABLE 5

EARLY YIELD OF FRUIT IN POUNDS FROM TOMATO PLANTS TREATED WITH 4-CPA IN WATER SPRAYS AND FROM UNTREATED PLANTS

\begin{tabular}{|c|c|c|c|c|c|c|c|}
\hline \multirow{3}{*}{ Treatments } & \multicolumn{7}{|c|}{ Test number, variety, and number of plants treated } \\
\hline & $\begin{array}{c}\text { Test } 5 \\
\text { Pearson } \\
80\end{array}$ & 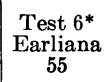 & $\begin{array}{l}\text { Test 13 } \\
\text { Pearson } \\
23\end{array}$ & $\begin{array}{c}\text { Test 15 } \\
\text { Earliana } \\
200\end{array}$ & $\begin{array}{l}\text { Test 19* } \\
\text { Earliana } \\
\quad 36\end{array}$ & $\begin{array}{c}\text { Test } 25 \dagger \\
\text { Pearson } \\
26\end{array}$ & $\begin{array}{c}\text { Test } 26 \\
\text { Earliana } \\
125\end{array}$ \\
\hline & $\begin{array}{c}\text { Pounds } \\
\text { per plant }\end{array}$ & $\begin{array}{c}\text { Pounds } \\
\text { per plant }\end{array}$ & $\begin{array}{c}\text { Pounds } \\
\text { per plant }\end{array}$ & $\begin{array}{c}\text { Pounds } \\
\text { per plant }\end{array}$ & $\begin{array}{c}\text { Pounds } \\
\text { per plant }\end{array}$ & $\begin{array}{c}\text { Pounds } \\
\text { per plant }\end{array}$ & $\begin{array}{c}\text { Pounds } \\
\text { per plant }\end{array}$ \\
\hline \multicolumn{8}{|l|}{$\begin{array}{l}\text { Treated } \\
\text { Water sprays }\end{array}$} \\
\hline 4-CPA, $25 \mathrm{ppm}$. & 0.52 & 7.7 & 1.11 & 2.1 & 0.98 & 15.0 & 0.98 \\
\hline 4-CPA, 50 ppm. & 0.82 & 9.9 & 1.03 & 2.4 & 1.09 & 26.7 & 0.85 \\
\hline 4-CPA, 100 ppm.. & 0.93 & 10.2 & $\ldots$ & 4.3 & 0.76 & 25.8 & 1.15 \\
\hline Untreated. . & 0.00 & 4.1 & 0.08 & 1.4 & 0.01 & 22.3 & 0.23 \\
\hline
\end{tabular}

* Sodium salt of 4-CPA used here instead of the acid.

$\dagger$ Concentrations used were 20,40 , and $80 \mathrm{ppm}$.

For dusts, as shown in table 3, the most effective concentrations in the few tests run were 500 to $1,000 \mathrm{ppm}$.

$\beta$-Naphthoxyacetic Acid and 2,4-Dichlorophenoxyacetic Acid. Data are too limited to be sure of the most effective concentration ranges for these 2 chemicals. However, for water sprays, a 2,4-D concentration of $10 \mathrm{ppm}$ was effective and is in the range used by other workers (Murneek et al., 1944; Strong, 1946 ; Zimmerman and Hitchock, 1942, 1944). For NOA, used at 50 to $500 \mathrm{ppm}$, the most effective concentrations of 250 and $500 \mathrm{ppm}$ were mainly higher than those reported by others (Gustafson, 1942; Howlett and Marth, 1946; Murneek et al., 1944; Roberts and Struckmeyer, 1944; Zimmerman and Hitcheock, 1944).

All 3 concentrations of 2,4-D in dusts increased fruit-set, as shown in table 3 , with 500 ppm the most effective.

NOA was used in aerosols at 110 and 1,130 ppm. The latter concentration set fruit while the 110 ppm was little better than the control.

For all 3 chemicals tested, the above data indicate that, in general, fruit-set based on count of immature fruit, or early yield, increased as the concentrations were raised. However, the concentration giving the greatest fruit-set is not necessarily the most desirable for practical application, and yields do not always correspond to the fruit counts made soon after treatment. Two factors-the effect of the chemical on plant injury and its effect on fruit size, the latter of which may be quite separate from its effect on fruit-set-account 
for this discrepancy. In the majority of the tests with 4-CPA, for example, $100 \mathrm{ppm}$ set the most fruit, but only in Tulare County did this concentration give materially better yields than the $50 \mathrm{ppm}$. Because of injury, it is important to know the minimum strength at which the chemicals will effectively set fruit. For 4-CPA we have selected $50 \mathrm{ppm}$ to be the most generally satisfactory concentration. This is higher than needed in some tests, but as our data show, the response to a minimum strength may vary greatly from test to test.

\section{Plant Injury Caused by Growth-Substance Treatments}

Injury to plants by low concentrations of growth substances is well known. It has been discussed by various workers in relation to fruit-set on tomatoes. In our work, malformed leaves were noticed in the first experiment and have been observed in most later tests.

Leaves which are fully expanded at the time of spraying for first setting show little response after the initial bending from which they soon recover, but leaves which develop soon after spraying may be markedly deformed. Sometimes the injury on tomatoes may be mistaken for cucumber mosaic or for severe tobacco mosaic. It results, for the most part, from failure of the leaf blades to expand. Because the treatment affects leaves which expand after application, the injury does not appear for 2 or more weeks, and is generally most severe on the branches bearing treated flower clusters. As growth continues, later developing leaves expand normally so that, several weeks after treatment, a plant may show injury at a certain height, yet have fully expanded leaves above and below this level. Since the injury appears on new growth, rapidly growing plants may show greater deformation than plants which are growing slowly or have ceased to grow. Other factors affecting the amount of injury may include concentration of chemical, number of treatments, extent of coverage, type of carrier, and chemical used. Tomato leaves injured by growth-regulating substances, in our experiments, agree well with the illustrations of Zimmerman et al. (1944, fig. $2 \mathrm{~A}$ and B), Zimmerman and Hitcheock (1942, fig. 5A), Murneek et al. (1944, fig. 2), and Strong (1946, figures 4 and 5 ).

Where water sprays of 4-CPA were applied to wet the flower clusters thoroughly, but to avoid the foliage as much as possible, $25 \mathrm{ppm}$ gave none to slight leaf deformation; $50 \mathrm{ppm}$, slight to moderate deformation; and $100 \mathrm{ppm}$, from slight to severe deformation. If the whole plant was wetted with $25 \mathrm{ppm}$, the foliage was severely injured. These ranges of deformation may be defined as follows: severely injured leaves look markedly stringy and grow more slowly than leaves on control plants ; slightly injured leaves show definite malformation, but usually are not checked in growth; moderate injury is a condition intermediate between these two extremes.

As with 4-CPA, concentrations of NOA and 2,4-D satisfactory for setting fruit are in a range where foliage injury becomes a problem. Our observations on 2,4-D would indicate that the injury by this chemical was especially persistent and somewhat localized.

Vegetative injury is a factor in limiting the uppermost concentration of growth substance in the carrier; it also dictates the method of application. 
While fruit-set may increase with greater concentrations of growth substance in the carrier, the practical range may be limited by injury. Although the hand application of spray to flower clusters is expensive, it is the only method of concentrating sufficient chemical on the flower parts while avoiding excessive application to the whole plant. Since aerosols and dusts cannot be easily confined to the flower clusters, they are less desirable carriers than water sprays.

\section{Growth Substances and Fruit Size}

Published data show that the size of fruit produced from treated flowers has been quite variable. That treated fruits are smaller than the controls or differ little in size has been found by several workers (Gustafson, 1940; Janes, 1941; Mitchell and Whitehead, 1942 ; Roberts and Struckmeyer, 1944; Schroeder, 1937). Others (Gustafson, 1942; Howlett, 1941; Howlett and Marth, 1946 ; Murneek et al., 1944; Strong, 1944, 1946; Wittwer et al., 1948) have found fairly consistent increases in size following treatment, and in some experiments (Hamner et al., 1944; Howlett, 1939; Strong, 1941) fruits both larger and smaller than the controls have been produced depending on the treatment.

There is evidence that the chemicals used (Howlett, 1939; Strong, 1941), methods of application (Hamner et al., 1944; Strong, 1941), age of flowers (Roberts and Struckmeyer, 1944), and environment (Gustafson, 1940 ; Howlett, 1941) may affect the relative size of the treated fruit.

The average weight of fruit from plants sprayed with 4-CPA and from unsprayed plants for several tests is given in table 6 . The mean fruit weight for all tests in the table is shown in the columns at the right. Because of the large sample size in test 6 , the mean that is not corrected for sample size is more representative of all the tests. These data show that fruits from treated plants were consistently largest. The increases ranged from slight in test 6 to double or more in tests 13 and 26. Other size data are given in table 3 . This increase in fruit size, apart from improved setting, may account for a considerable portion of the early yield from treated plants.

The extent to which treatment may affect both market grade and yield through its effect on fruit size is indicated by the data from test 2 given in table 7. The tomatoes in test 2 were sorted into size classes commonly used in packing for the market, and the number and weight of fruit in each class are shown. The large and medium classes contain about 80 per cent by weight of the fruit from the treated lot and around 50 per cent from the untreated. Similarly the very small class contains about 3 per cent of the fruit from the treated lot and about 19 per cent from the untreated. While it is advantageous to incredse the size of very small fruit, increasing the size of all fruit may be of no particular market advantage. However, the increase in yield must be considered. In this experiment, yield of the marketable fruit was increased about 45 per cent by the larger size alone.

In all of our tests, fruits set by the treatments were larger than fruits from the check plants. However, the size of fruits from treated flowers varied with the chemical used, its concentration, and the carrier. Fruit size increased with increasing concentration of the chemical with aerosol application, 2,4-D water sprays, and, as shown in table 3, with dust applications of 2,4-D and 


\begin{tabular}{|c|c|c|c|c|c|c|c|c|}
\hline $\begin{array}{l}\vec{J} \\
\dot{H} \\
\dot{d}\end{array}$ & \multirow{2}{*}{\multicolumn{3}{|c|}{ 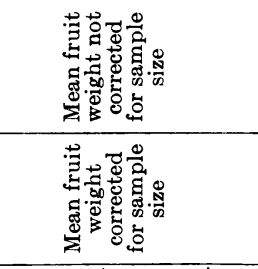 }} & $\begin{array}{c}\stackrel{2}{0} \\
\stackrel{0}{0} \\
0\end{array}$ & $\underset{\substack{0 \\
0}}{0}$ & 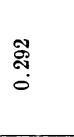 & $\begin{array}{l}\text { สึ } \\
0\end{array}$ & \\
\hline$\vec{E}$ & & & & 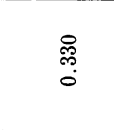 & $\underset{m}{m}$ & $\begin{array}{l}\stackrel{0}{m} \\
0 \\
0\end{array}$ & 市 & \\
\hline & \multirow{16}{*}{ 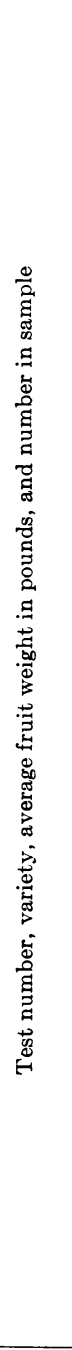 } & \multirow{2}{*}{ 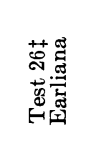 } & $\dot{g}$ & 哭 & 常 & 突 & $\vec{\infty}$ & \\
\hline 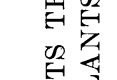 & & & $\dot{B}$ & $\stackrel{\text { డ్ }}{0}$ & 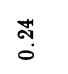 & $\stackrel{\text { ্ֻ }}{0}$ & $\stackrel{0}{0}$ & \\
\hline 出出 & & \multirow{2}{*}{ 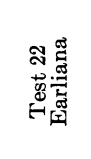 } & $\dot{g}$ & $\vec{m}$ & $\stackrel{1}{.}$ & $\hat{\mathfrak{9}}$ & \&్ల & \\
\hline 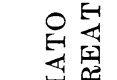 & & & $\dot{B}$ & 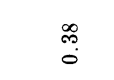 & 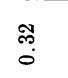 & స̃. & 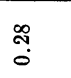 & \\
\hline 员 & & \multirow{2}{*}{ 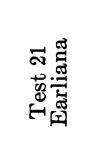 } & $\dot{\AA}$ & : & $\stackrel{\wp}{\circledR}$ & $\vdots$ & \&్ల & \\
\hline 它罢 & & & $\dot{B}$ & $\vdots$ & $\begin{array}{l}\vec{p} \\
0 \\
0\end{array}$ & $\vdots$ & ホ⿱ & \\
\hline 受最 & & \multirow{2}{*}{ 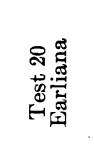 } & $\dot{\AA}$ & $\stackrel{8}{\circ}$ & $\vdots$ & $\vdots$ & $\frac{\pi}{\pi}$ & \\
\hline 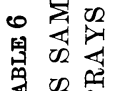 & & & $\dot{B}$ & $\stackrel{\ddot{g}}{0}$ & $\vdots$ & $\vdots$ & $\stackrel{\substack{0 \\
0}}{0}$ & \\
\hline 定 & & \multirow{2}{*}{ 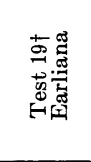 } & $\dot{a}$ & J & $\stackrel{\vec{N}}{a}$ & Iี & $\stackrel{\infty}{=}$ & 9 \\
\hline 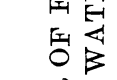 & & & $\dot{B}$ & 망 & $\stackrel{\tilde{\tilde{m}}}{0}$ & 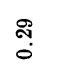 & స̃. & $\begin{array}{l}\text { क } \\
8 \\
8\end{array}$ \\
\hline 琴台 & & \multirow{2}{*}{ 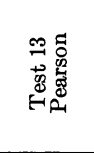 } & $\dot{g}$ & $\Re$ & 8 & : & $\exists$ & \\
\hline 爷星 & & & $\dot{\vec{B}}$ & $\begin{array}{l}\infty \\
\infty \\
0\end{array}$ & $\begin{array}{l}\mathscr{\infty} \\
0 \\
0\end{array}$ & $\vdots$ & $\stackrel{\Re}{\circ}$ & \\
\hline 学官 & & \multirow{2}{*}{ 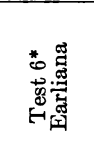 } & $\dot{g}$ & 话 & $\begin{array}{l}\substack{\infty \\
0 \\
\infty \\
-1} \\
-1\end{array}$ & 芯 & 㤐 & \\
\hline 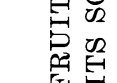 & & & $\dot{\vec{B}}$ & $\vec{m}$ & 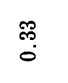 & $\stackrel{\mathscr{N}}{\circ}$ & ণ্ণ & \\
\hline 덩 렁 & & \multirow{2}{*}{ 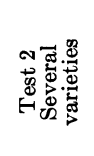 } & $\dot{g}$ & : & ి્. & $\vdots$ & $\infty$ & \\
\hline 预 & & & $\dot{\vec{B}}$ & $\vdots$ & $\stackrel{\pi}{*}$ & : & $\overrightarrow{0}$ & \\
\hline 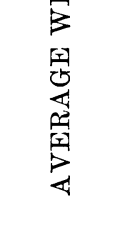 & & \multicolumn{2}{|l|}{ 莺 } & 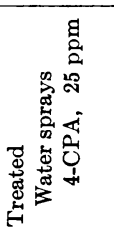 & 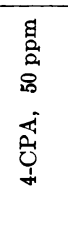 & 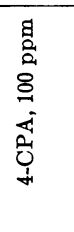 & 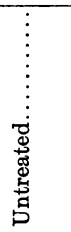 & 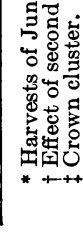 \\
\hline
\end{tabular}


4-CPA. In contrast, as shown in table 6 , fruit size decreased with increasing concentrations of 4-CPA water sprays, the $25 \mathrm{ppm}$ giving the largest fruit. These data suggest that, for 4-CPA water sprays the optimum concentration for increasing fruit size is below the optimum for fruit-set. In tests 14 and 21 for instance, fruits from treated flowers were larger, even though set was not increased. This means, from the standpoint of yield, that the larger number of fruits set by a $100 \mathrm{ppm}$ spray may be balanced by the larger size of fruit from a $25 \mathrm{ppm}$ spray. Using the fruit-size figures for the 100 and $25 \mathrm{ppm}$ sprays shown in the last column in table 6 , the $100 \mathrm{ppm}$ spray would have to set about 20 per cent more fruit than the $25 \mathrm{ppm}$ to give an equal yield by weight.

TABLE 7

SIZE, GRADE, AND EARLY YIELDS OF FRUIT FROM TOMATO PLANTS TREATED* WITH A WATER SPRAY OF 50 PPM OF 4-CPA AND FROM UNTREATED PLANTS

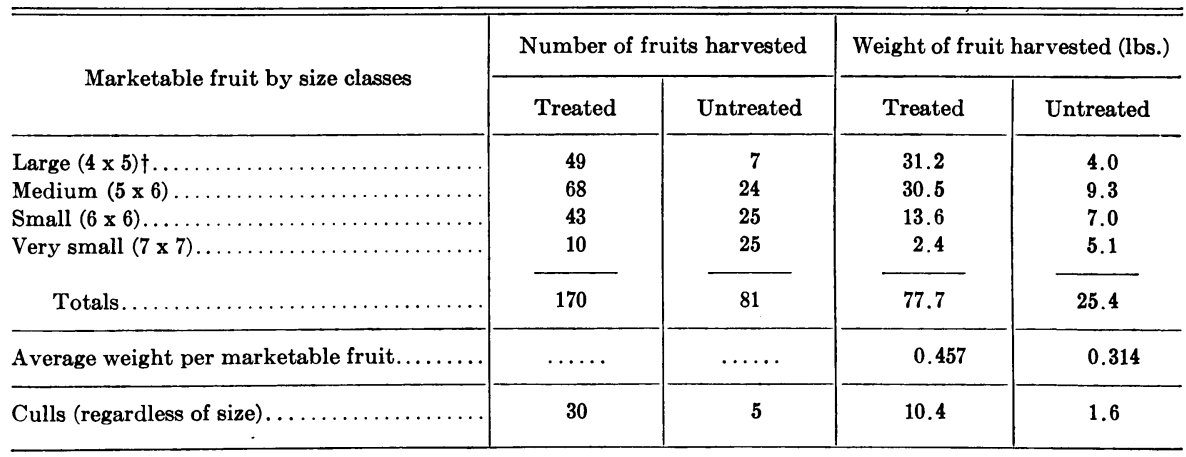

* Sprayed June 14 and harvested August 8 ; yield from 1 previous light picking not obtained. Approximately 270 plants in each treatment. Test 2 of table 1 .

$t$ This refers to the number of rows and fruit per row on the face of a standard lug.

At present these relationships of fruit size to growth-substance treatments are not well understood. Gustafson (1940) has suggested that the supply of food and auxin determines the final size attained by developing fruit, and that competition among the fruits on the vine must be considered. Our data indicate that for field-grown vines under the conditions of our tests food is not limiting, since the treated plants not only set more fruit than check plants but also produced a consistently larger fruit. For water sprays of 4-CPA, the growth-substance supply would seem adequate, since the $25 \mathrm{ppm}$ treatment produced larger fruits than the higher concentrations.

Howlett (1941) has pointed out that the size of untreated fruits may depend largely upon the number of seeds each contains, those with few seeds being small. When conditions are unfavorable for fruit-set, naturally set fruits are likely to contain few seeds; when the size of these fruits is compared with the size of fruits set by growth substances, the comparison may favor the latter. However, the fruits set by growth substances in our tests were generally of desirable market size. To what extent growth substances can increase the size of tomato fruits when conditions are favorable for natural setting is not known. 


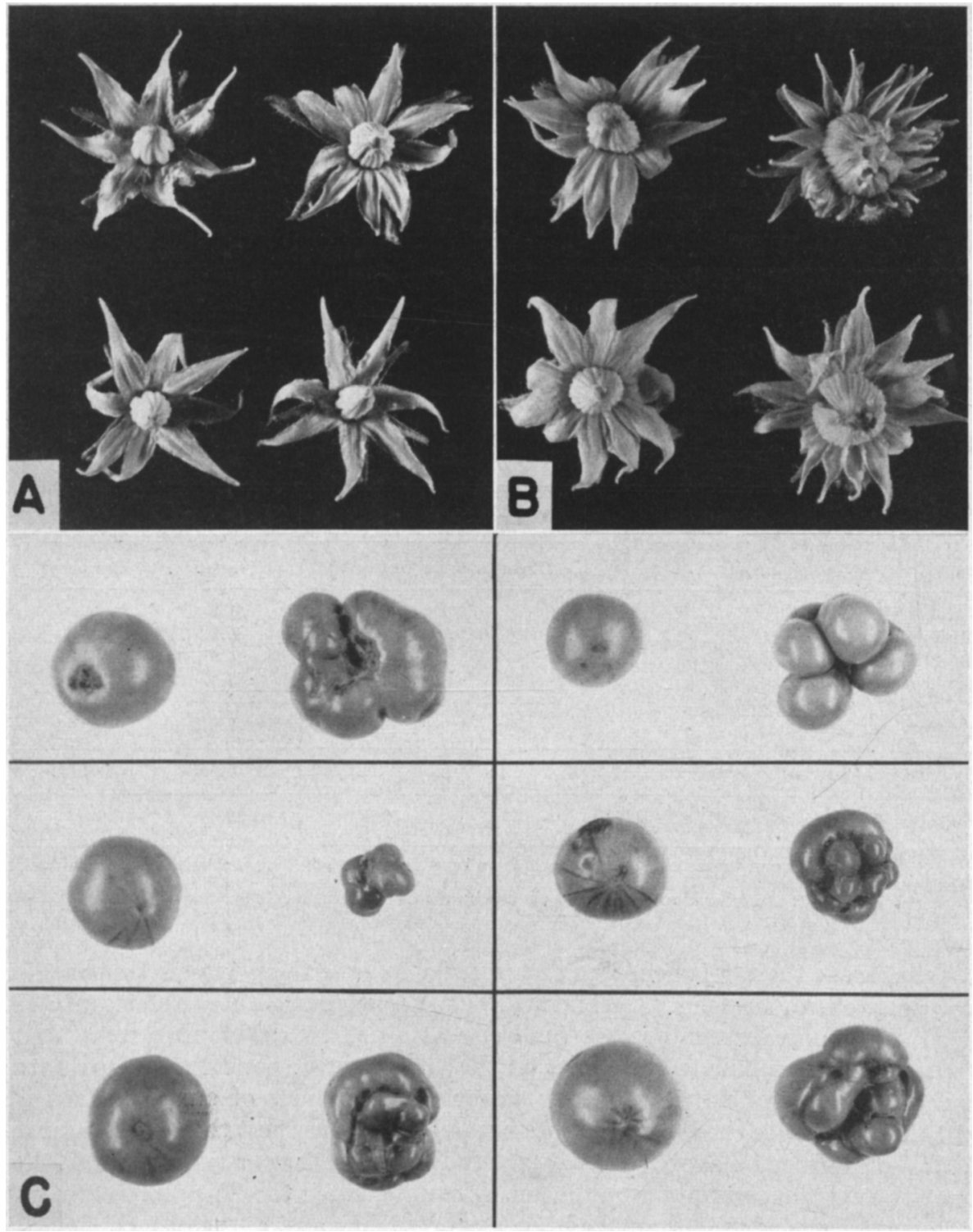

Fig. 2. $A$, flowers of the Earliana variety showing the usual arrangement and number of flower parts. $B$, fasciated flowers with numerous stamens and petals. These flowers are typical of the first flower to open on the crown cluster. $C$, Earliana fruits from erown clusters which were treated with a growth regulator. Both fruits of each pair are from the same cluster. The right hand fruit in each pair came from a fasciated flower (tagged at time of anthesis), while the other fruit developed from a flower of normal appearance. 


\section{Growth Substances and Fruit Quality}

It should be stressed that for tomatoes set by growth substances, the gain in yield from either better set or larger size must be evaluated against fruit quality. While some workers (Gustafson, 1942; Mitchell and Whitehead, 1942) have set parthenocarpic fruit which, except for lack of seeds, is quite normal, other workers (Hamner et al., 1944; Howlett, 1941, 1943; Howlett and Marth, 1946; Janes, 1941; Roberts and Struckmeyer, 1944; Strong, 1946), at least with some treatments, have observed such defects as hollow locules (puffiness), fruits too solid-for instance, lack of gelatinous pulp-a condition similar to blossom-end rot, internal discoloration, green gelatinous pulp in the ripe fruit, susceptibility to cracking, and undesirable fruit shape.

Observatons on fruit quality in the tests of table 1 are summarized below under the various defects.

Fruit Shape. Fruits from the earliest pickings after a $50 \mathrm{ppm}$ 4-CPA water spray in tests 21 and 22 were graded severely for roughness (lobed, multiple, or partly separated fruit) and blossom-end scars. In test 21 , rough fruit made up 33 per cent of the check and 45 per cent of the treated lots, and in test 22 , 14 per cent and 30 per cent, respectively. Where considerable natural roughness occurs, as in these 2 tests, it might be expected that growth substances would accentuate this defect. However, roughness is not always increased by treatment. In test 1 , following a $50 \mathrm{ppm} 4-\mathrm{CPA}$ water spray, of 48 treated fruits, only 1 was rough, while the check had no rough fruit. In test 6 the percentages of culls from all causes from plants treated with 25, 50, and 100 ppm 4-CPA water sprays were 20.7, 15.4, and 13.7 per cent by count, respectively. The check plot had 22.2 per cent culls. These figures are from samples of around 800 to 2,000 fruits for each treatment (table 6). The fruits were harvested from June 6 to June 22, the period in which the fruit set by the treatment was ripening (table 12).

It is well known that the first fruits from early plantings are generally rougher than those harvested from the same vines later in the season. In the first few clusters formed, the first flower to open is often obviously fasciated. The ovaries of these flowers may be lobed or separated into parts, frequently with multiple stigmas and styles, and, if set, they produce misshapen fruit. This flower condition and the type of fruit produced are shown in figure 2. These malformed flowers frequently do not set naturally, but, if induced to set by treatment, they necessarily increase the proportion of misshapen fruit. Thus, without being the primary cause of roughness in fruit, growth substances may increase the proportion of rough fruit in an early harvest.

Treated fruits have been slightly but quite consistently pointed in most tests, similar to those illustrated by Strong (1946, figures 3 and 7) and Murneek et al. (1944, figures 3 and 4). Growers have not found this a disadvantage in grading or packing. We have not observed pear-shaped fruit caused by enlargement of the style (Howlett, 1941).

Sunburn. Where growth substances cause moderate to severe vine injury, the reduced foliage protection may permit excessive sunburning of the fruit. Although in most of our tests sunburning has not been serious, in 1 test in the Central Valley, where fruit ripened during hot weather, 32 per cent 
showed sunburning on plants treated with $100 \mathrm{ppm}$ 4-CPA water sprays, compared with 14 per cent on the check. Accordingly, if sunburning is a problem on untreated plants, growth substances should be used very cautiously.

Green Gelatinous Pulp. Persistence of green color in the seed cavity was noted in some fruit from several of the tests. In test 25, where Pearson tomatoes for canning were sprayed with 4-CPA, samples of ripe fruit showed 39 per cent with green pulp from the check plots compared with 39,55 , and 68 per cent for the plots treated with 20,40 , and $80 \mathrm{ppm}$, respectively. This indicated that use of the chemicals at higher concentrations may increase the disorder. Casual observations on other tests indicate that this disorder is not

TABLE 8

NUMBER OF BUDS, FLOWERS, AND FRUITS ON FLOWER CLUSTERS TREATED* WITH A 50 PPM 4-CPA WATER SPRAY AND ON UNTREATED FLOWER CLUSTERS

\begin{tabular}{|c|c|c|c|c|c|c|}
\hline \multirow{3}{*}{$\begin{array}{l}\text { Stage of flower development } \\
\text { on clusters }\end{array}$} & \multicolumn{3}{|c|}{ Treated } & \multicolumn{3}{|c|}{ Untreated } \\
\hline & \multicolumn{3}{|c|}{ Counts on dates indicated } & \multicolumn{3}{|c|}{ Counts on dates indicated } \\
\hline & June 2 & June 14 & July 5 & June 2 & June 14 & July 5 \\
\hline Buds. . & 38 & 26 & .. & 42 & 17 & .. \\
\hline Open flowerst. & 28 & 4 & .. & 31 & 25 & .. \\
\hline Drying flowers. & 3 & 2 & .. & 0 & 39 & $\begin{array}{l}\cdots \\
\ldots\end{array}$ \\
\hline Abscissed flowers... & 0 & 0 & .. & 0 & 4 & 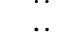 \\
\hline Fruit set..... & 0 & 43 & 42 & 0 & 3 & 35 \\
\hline Total. & 69 & 75 & .. & 73 & 88 & . \\
\hline
\end{tabular}

* Stone variety treated June $2 ; 12$ clusters in each group. Test 1 of table 1.

$\dagger$ Counted as open if calyx and corolla were beginning to separate.

sufficiently serious to be a problem with tomatoes used for fresh market. In canning, where good color is especially important, green pulp in the fruit might be undesirable.

Puffy Fruits. Samples of 100 fruits in test 25 had 5 puffy fruits from the check plot, and 7, 9, and 23 from the plots sprayed with 20,40 , and $80 \mathrm{ppm}$ of 4-CPA, respectively. We have examined fruit for this defect in many other tests, and puffiness has seldom been so bad as in the above test.

The growth substances we used did not produce internal discoloration (other than green pulp) or disorders similar to blossom-end rot.

\section{Age of Flowers Treated and Fruit-set}

The length of time over which an individual flower is receptive to setting by spray treatment determines, to a great extent, the number of fruits which can be set by a single treatment, and also the time-lapse between treatments if more than one is given. The stage of development at which flowers can be set as well as the effect of spraying on further cluster development can be determined from data taken on test 1 . Buds, flowers, and fruits were counted on 24 tagged flower clusters, each on a separate plant, and half were treated with a water spray of $50 \mathrm{ppm}$ of 4-CPA on June 2 . Further counts were taken on June 14 and on July 5 as shown in table 8. 
Between June 2 and 14, conditions were unfavorable for fruit-set. On the check clusters, flowers open on June 2 were mostly withered by June 14, but were largely replaced by opening buds. After June 14 conditions became favorable for fruit-setting on these clusters.

On the treated clusters, fruits were set with no withering or drop of flowers. The number of fruits on June 14 indicates that all open flowers and 35 to 40 per cent of the buds had been set by the spraying on June 2. Growth and opening of small buds on the treated clusters appear to have been retarded either by the chemical or perhaps by growth of the fruit, and few fruits set after

TABLE 9

FRUIT SIZE, NUMBER OF FRUITS SET, AND PER CENT OF FLOWERS SET ON TOMATO CLUSTERS TREATED WITH A 50 PPM 4-CPA WATER SPRAY*

\begin{tabular}{|c|c|c|c|c|}
\hline & \multicolumn{2}{|c|}{ One cluster sprayed per plant } & \multicolumn{2}{|c|}{ All clusters sprayed } \\
\hline & $\begin{array}{l}\text { Tagged } \\
\text { clusters }\end{array}$ & $\begin{array}{c}\text { Remaining } \\
\text { clusters }\end{array}$ & $\begin{array}{l}\text { Tagged } \\
\text { clusters }\end{array}$ & $\begin{array}{c}\text { Remaining } \\
\text { clusters }\end{array}$ \\
\hline $\begin{array}{l}\text { Total number of flowers at time of treatment } \\
\text { Open or showing color. } \ldots \ldots \ldots \ldots \ldots \ldots \ldots \ldots \\
\text { Corolla drying. } \ldots \ldots \ldots \ldots \ldots \ldots \ldots \ldots \ldots\end{array}$ & $\begin{array}{r}51 \\
2\end{array}$ & $\begin{array}{r}339 \\
15\end{array}$ & $\begin{array}{r}68 \\
2\end{array}$ & $\begin{array}{r}320 \\
16\end{array}$ \\
\hline Total fruit set, May $21 \ldots \ldots \ldots \ldots$ & 52 & 36 & 56 & 296 \\
\hline Fruit set as per cent of flowers............. & $98 \% \dagger$ & $10 \% \dagger$ & $80 \% \dagger$ & $88 \% \dagger$ \\
\hline 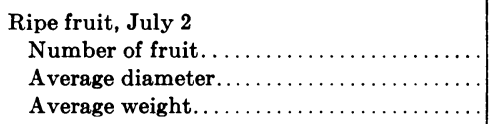 & $\begin{array}{l}44 \\
7.50 \mathrm{~cm} . \\
0.345 \mathrm{lbs} .\end{array}$ & $\begin{array}{l}\cdots \\
\cdots \\
\cdots\end{array}$ & $\begin{array}{l}34 \\
7.23 \mathrm{~cm} . \\
0.282 \mathrm{lbs} .\end{array}$ & $\begin{array}{l}\cdots \\
\cdots \\
\cdots\end{array}$ \\
\hline
\end{tabular}

* One flower cluster tagged and sprayed on each of 20 plants; on 10 of the plants all other flower clusters also sprayed. Earliana variety, treated May 11. Test 23 of table 1 .

$\dagger$ Buds were not counted, but a few may have set, which would modify this figure.

June 14. The larger total count of buds, flowers, and fruit on June 14 came from the development of buds less than 1 millimeter long, which were not counted on June 2.

These data indicate that flowers respond to the growth substances from the stage of large buds until the corolla dries. This means that individual flowers are receptive for a week or more, and that by proper timing, one treatment may set a large proportion of the flowers of a single cluster. It also suggests that, at least for this variety, further treatment should be applied only after additional flower clusters have appeared. This is essentially in agreement with the observations of Roberts and Struckmeyer, 1944, and Zimmerman and Hitchcock, 1942, 1944, on greenhouse tomatoes.

\section{Number of Flowers Treated per Plant and Fruit-set}

It is desirable to know how fruit-set and size are affected by the number of flower clusters treated per plant. In test 23,20 plants each with 5 or more clusters showing open flowers were selected and one cluster was tagged on each plant. On 10 plants only the tagged cluster was sprayed while on the other 10 plants all clusters were treated. A water spray of $50 \mathrm{ppm}$ of 4-CPA was used. Data from these plants are shown in table 9. 
This table shows that on May 21, 88 fruits had set on the 10 plants where the tagged clusters only were sprayed and 352 where all clusters were sprayed. The per cent of fruit set, as well as the average diameter and weight of fruit from the tagged clusters, was reduced by spraying all clusters on the plant. The reduction in average fruit weight was about 18 per cent. Comparing the total number of fruits set on the 2 groups of plants, the differences found in fruit size and set on the tagged clusters are surprisingly small.

For the Earliana variety, it appears that treating only a few of the flower clusters on a vine bearing many clusters would net only a small increase in average fruit size for a considerable sacrifice in total fruit set. The response to the number of flowers treated would be expected to vary with the vigor and size of the plant. The vines in this experiment were growing vigorously, and practically no natural setting of fruit had taken place.

\section{Use of Growth Substances on Canning Tomatoes}

Three tests-12, 14, and 25-were conducted on tomatoes grown for canning. In test 25, water sprays of 4-CPA were applied by airplane and by hand sprayer. The yield on the check plots was good; the treated plots showed very little benefit at the first picking. In tests 12 and 14, where the treatments were applied by hand, the natural set was only fair; the treatments did not improve set materially. The good natural set found in test 25 is the usual condition in most years in the major canning areas. Only occasionally is set delayed to the extent that a crop is endangered by early rains or by frosts. We are unable to explain the failure of the treatments to increase set in tests 12 and 14.

These results suggest that the use of growth substances on canning tomatoes is not too promising. In addition the hand method of applying chemicals to the flower cluster only is not well adapted to the canning crop; machine application must be achieved if growth regulators are to be practical. Since total yield is usually more important than early yield, growth substances should be used cautiously on the canning crop to avoid the danger of reducing late-season yields by moderate to severe plant injury. However, in view of the results on early-market tomatoes, it is possible that growth substances might prove profitable in certain years or in certain areas.

\section{Yield Patterns Following Growth-substance Treatments}

The tomato grower using growth-regulating substances must not only know what chemicals are satisfactory, and how and when they should be applied, but also the approximate time interval between treatment and harvest, the duration of the harvest period, and the expected yield from plants following the period when chemically set fruits have been picked. The time interval from treatment to harvest for 13 tests is summarized in table 10, and the general yield pattern for treated and untreated plots will be illustrated by yield curves and figures for 3 tests representing a range of growing conditions and times of treatment.

In recording the number of days between treatment and harvest we have used two terms : first harvest, to designate the date the first fruits set by the chemical were picked; and peak harvest, to designate the date of maximum 
yield during the period when fruit set by the growth substance was ripening. The time intervals for untreated plants were not obtained because peak yields do not occur with untreated plants and the date of setting cannot be determined readily.

For Earliana, the peak harvest came from 49 to 58 days after treatment, and for Pearson, from 56 to 70 days. These data are useful in predicting when fruit from treated plants can be expected to ripen. As will be shown later, fruit set by a single treatment does not ripen all at once, and harvesting

TABLE 10

INTERVAL IN DAYS FROM TIME OF TREATMENT OF TOMATO CLUSTERS TO FIRST RIPENING OF FRUIT AND TO PEAK EARLY HARVEST

\begin{tabular}{|c|c|c|c|c|c|}
\hline Test number & Variety & $\begin{array}{l}\text { Clusters } \\
\text { treated* }\end{array}$ & $\underset{\text { treated }}{\text { Date }}$ & $\begin{array}{c}\text { Days to first } \\
\text { harvest }\end{array}$ & $\begin{array}{c}\text { Days to peak } \\
\text { harvest } \dagger\end{array}$ \\
\hline $1 \ldots$ & Stone & Late & June 14 & 52 & .. \\
\hline $5 \ldots \ldots \ldots \ldots \ldots \ldots \ldots \ldots \ldots \ldots \ldots \ldots \ldots \ldots \ldots \ldots \ldots$ & Pearson & Crown & April 24 & 57 & 62 \\
\hline $6 \ldots \ldots \ldots \ldots \ldots \ldots \ldots \ldots \ldots \ldots \ldots$ & Earliana & Late & April 18 & 52 & 58 \\
\hline $13 \ldots \ldots \ldots \ldots \ldots \ldots \ldots \ldots \ldots \ldots$ & Pearson & Crown & April 13 & 59 & 70 \\
\hline $15 \ldots \ldots \ldots$ & Earliana & Late & April 22 & 52 & 57 \\
\hline $17 \ldots$ & Pearson & Late & May 1 & 47 & 56 \\
\hline $18 \ldots$ & Earliana & Crown & April 10 & 43 & $48-57$ \\
\hline $18 \ldots$ & Earliana & Late & April 21 & . & 50 \\
\hline $19 \ldots$ & Earliana & Crown & April 19 & 47 & 52 \\
\hline $19 \ldots$ & Earliana & Late & May 10 & 43 & 51 \\
\hline $20 \ldots \ldots \ldots$ & Earliana & Late & May 10 & . & 51 \\
\hline $24 \ldots$ & Earliana & Late & May 14 & 37 & 49 \\
\hline $26 \ldots \ldots \ldots \ldots \ldots \ldots$ & Earliana & Crown & April 23 & .. & 50 \\
\hline
\end{tabular}

* Crown refers to first flower cluster on plant and late refers to any clusters following the crown cluster.

$\dagger$ Peak harvest refers to the date of maximum yield during the period when fruit set by the growth substance was ripening.

may extend over a period of 2 weeks. In California, market tomatoes are harvested at stages from mature green to full ripe, depending on the market outlet. Fruits in most of our tests were harvested at the breaker or pink stage. The differences in stage of harvesting account for some of the range in days among peak harvests.

The general yield pattern of tomato plots following growth-substance treatment is given in table 11 and figure 3 for test 15, and in table 12 and figure 4 for test 6.

For both of these tests figures 3, top and 4, top showing yield by pickings have lines drawn along the abscissa to designate the harvest dates when fruit set by the treatment was picked. This covers the period of 52 to 64 days after treatment for test 15 and 49 to 65 days for test 6 . Yields in tables 11 and 12 are summed for these same periods and also for harvests preceding and following these periods.

While it is obvious that the harvest data from these 2 tests differ in several respects, such as the relative effectiveness of the $100 \mathrm{ppm}$ sprays, we have observed certain yield patterns common to these and to other tests.

For both tests the differences in yield between treated and check plots are large during the time the chemically set fruit was harvested. As has been true with most of our tests, the check yielded poorly during this period, but by the time the yield from the treated plots was slacking, the check was yielding 

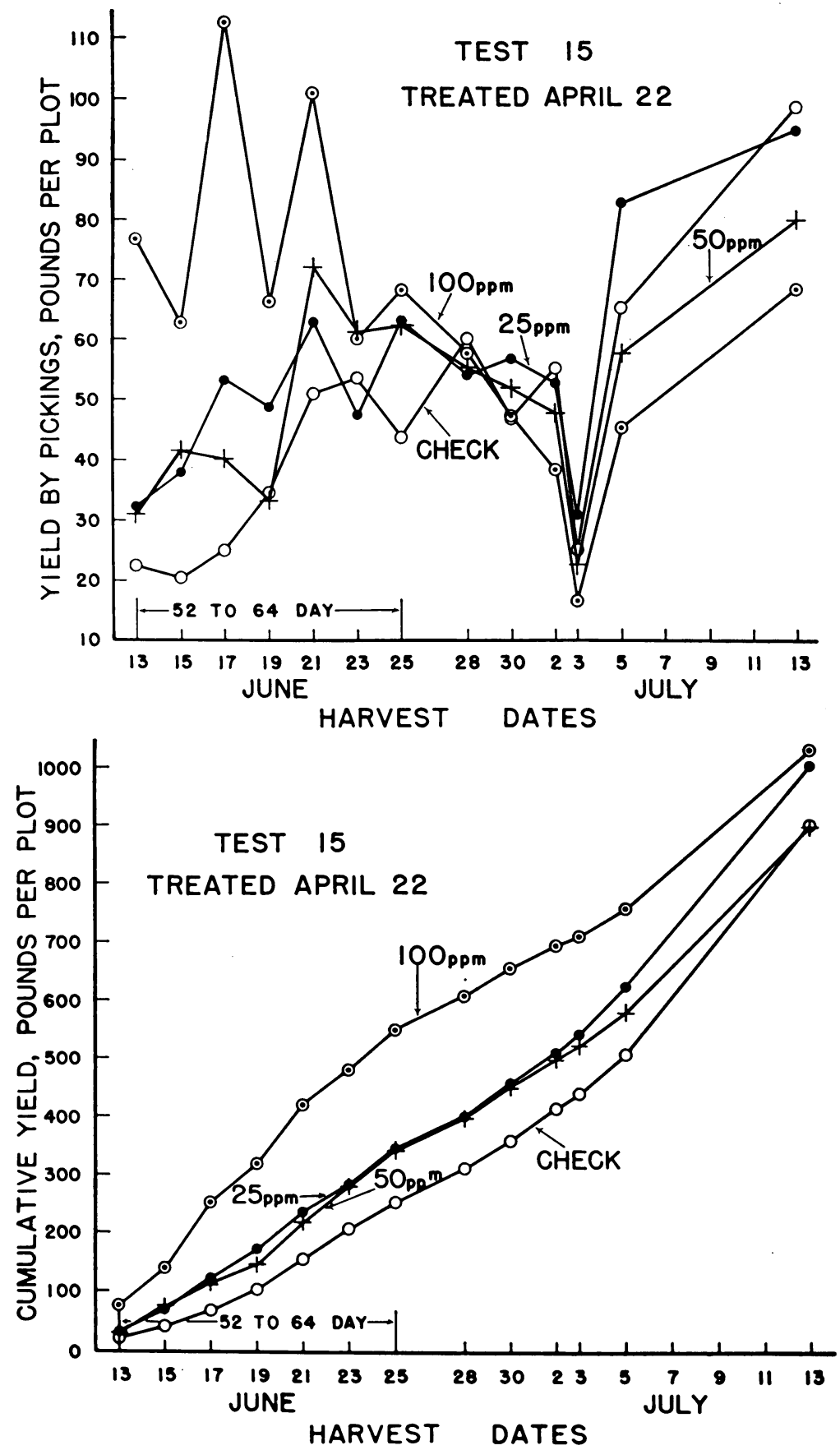

Fig. 3. Top, yield of fruit of the Earliana variety by pickings, and cumulative yield, bottom, in pounds per plot from plants treated with three concentrations of 4-chloros phenoxyacetic acid in water sprays, and from untreated plants. Each point represents the yield of 100 plants and is the average of 4 plots of 100 plants each. For each concentration level, 2 of the 4 plots were treated with the acid form of the growth substance, and 2 with the Na salt. Separate yields of pickings made July 7, 9, 11, and 13 were not available, and are averaged for July 13. 
TABLE 11

YIELDS OF FRUIT DURING SELECTED HARVEST PERIODS IN POUNDS PER PLANT AND LUGS PER ACRE FROM TOMATO PLANTS* TREATED WITH THREE CONCENTRATIONS OF 4-CPA $\dagger$ WA'TER SPRAYS AND FROM UNTREATED PLANTS

\begin{tabular}{|c|c|c|c|c|c|c|}
\hline \multirow{3}{*}{ Treatments } & \multicolumn{4}{|c|}{ Yield by periods } & \multirow{2}{*}{\multicolumn{2}{|c|}{$\frac{\text { Total Yield }}{\text { June } 13 \text { to July } 13}$}} \\
\hline & \multicolumn{2}{|c|}{ June 13 to June 25} & \multicolumn{2}{|c|}{ June 28 to July 13} & & \\
\hline & $\begin{array}{c}\text { Pounds } \\
\text { per plant }\end{array}$ & $\begin{array}{c}\text { Lugs } \\
\text { per acre }\end{array}$ & $\begin{array}{l}\text { Pounds } \\
\text { per plant }\end{array}$ & $\begin{array}{c}\text { Lugs } \\
\text { per acre } \ddagger\end{array}$ & $\begin{array}{c}\text { Pounds } \\
\text { per plant }\end{array}$ & $\begin{array}{c}\text { Lugs } \\
\text { per acre }\end{array}$ \\
\hline Untreated.. & 2.50 & 401 & 6.45 & 1,036 & 8.95 & 1,437 \\
\hline Treated, water spray & & & & & & \\
\hline 4-CPA, 25 ppm... & 3.45 & 554 & 6.54 & 1,050 & 9.98 & 1,604 \\
\hline $4-\mathrm{CPA}, \quad 50 \mathrm{ppm} \ldots \ldots \ldots \ldots \ldots \ldots$ & 3.36 & 540 & 6.26 & 1,005 & 9.62 & 1,545 \\
\hline 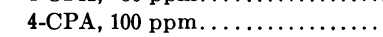 & 5.47 & 878 & 4.77 & 766 & 10.24 & 1,644 \\
\hline $\begin{array}{l}\text { Harvest period, days after } \\
\text { treatment.............. }\end{array}$ & \multicolumn{2}{|c|}{52 to 64} & \multicolumn{2}{|c|}{67 to 82} & \multicolumn{2}{|c|}{52 to 82} \\
\hline
\end{tabular}

* Earliana variety sprayed April 22 at general bloom stage; each treatment on 400 plants. Test 15 of table 1. salt.

$\dagger$ Each treatment shows the combined yield from 2 rows treated with the acid and 2 treated with the sodium $\ddagger 35$-pound packed lugs.

TABLE 12

YIELDS OF FRUIT DURING SELECTED HARVEST PERIODS IN POUNDS PER PLANT FROM PLANTS* TREATED WITH THREE CONCENTRATIONS OF Na-4-CPA WATER SPRAYS AND FROM UNTREATED PLANTS

\begin{tabular}{|c|c|c|c|c|}
\hline \multirow{2}{*}{ Treatments } & \multicolumn{3}{|c|}{ Yield by periods } & \multirow{2}{*}{$\begin{array}{c}\text { Total yield } \\
\begin{array}{c}\text { May } 25 \\
\text { to July } 2\end{array}\end{array}$} \\
\hline & $\begin{array}{c}\text { May } 25 \\
\text { to June } 3\end{array}$ & $\begin{array}{c}\text { June } 6 \\
\text { to June } 22\end{array}$ & $\begin{array}{c}\text { June } 25 \\
\text { to July } 2\end{array}$ & \\
\hline & $\begin{array}{c}\text { Pounds } \\
\text { per plant }\end{array}$ & $\begin{array}{l}\text { Pounds } \\
\text { per plant }\end{array}$ & $\begin{array}{l}\text { Pounds } \\
\text { per plant }\end{array}$ & $\begin{array}{l}\text { Pounds } \\
\text { per plant }\end{array}$ \\
\hline Untreated... & 0.54 & 4.51 & 2.46 & 7.5 \\
\hline \multicolumn{5}{|l|}{ Treated, water spray } \\
\hline 4-CPA, 25 ppm... & - 0.76 & 8.76 & 1.83 & 11.35 \\
\hline $4-\mathrm{CPA}, \quad 50 \mathrm{ppm} \ldots$ & 0.74 & 11.14 & 1.03 & 12.91 \\
\hline 4-CPA, 100 ppm.... & 0.67 & 11.26 & 0.96 & 12.89 \\
\hline Harvest period, days after treatment... & 37 to 46 & 49 to 65 & 68 to 75 & 37 to 75 \\
\hline
\end{tabular}

* Sprayed April 18 at general bloom stage; 55 plants per treatment. Earliana variety. Test 6 of table 1.

fairly well. Following the period when fruit set by the treatments was harvested, the plots receiving the higher concentrations-100 and $50 \mathrm{ppm}-$ yielded less than the check or the $25 \mathrm{ppm}$ treatment. This is most evident in figures 3, top and 4, top, and from the tabulated yields for the last part of the harvest season as shown in tables 11 and 12 .

In tests 6 and 15 the harvest period was relatively short because of market conditions. These short harvest periods are common in the early-market areas even though fields are still yielding well. If the yield trends present in the last few pickings from these 2 tests continued, there would be little difference 

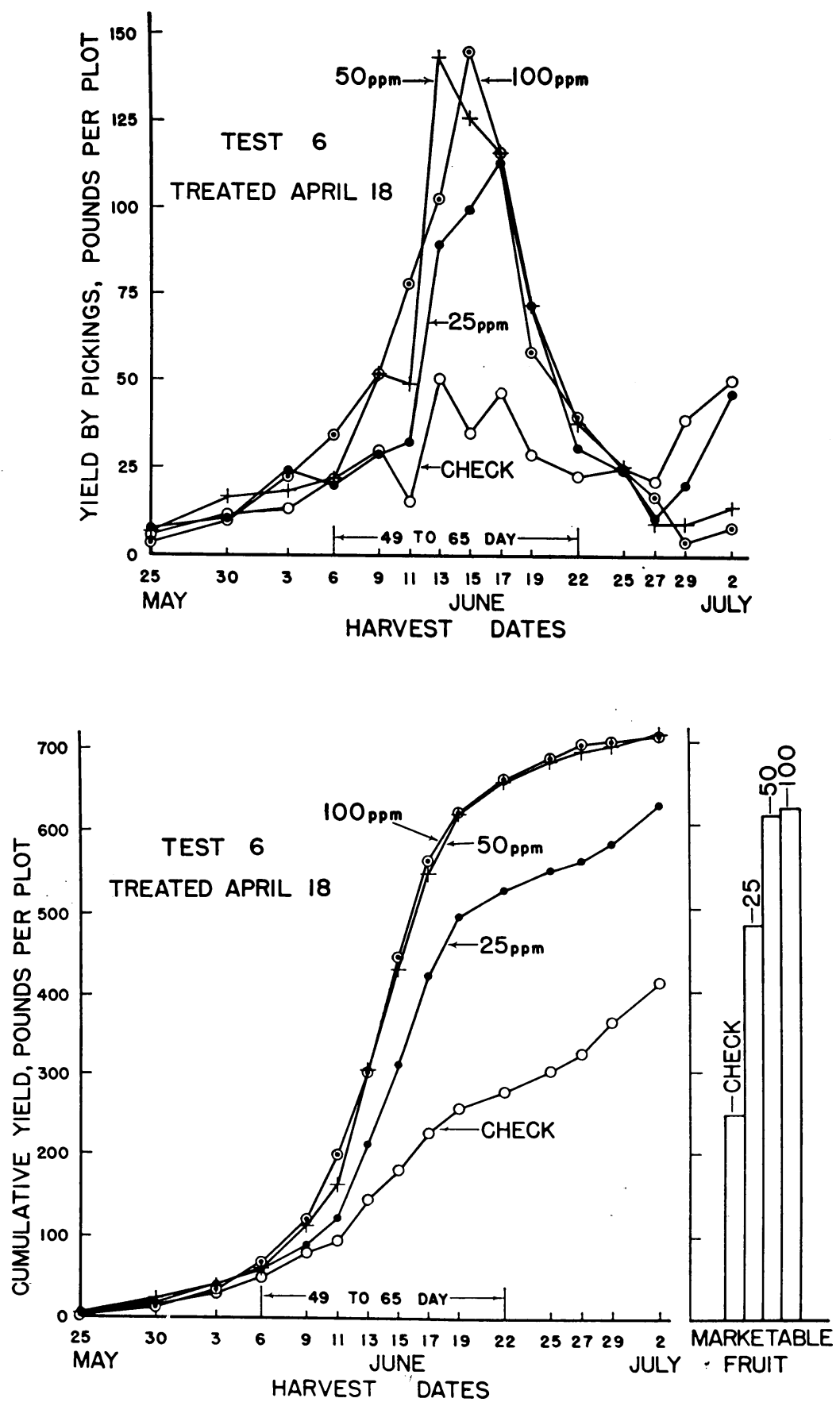

Fig. 4. Top, yield of fruit of the Earliana variety by pickings, and cumulative yield, bottom, in pounds per plot from plants treated with three concentrations of 4-chlorophenoxyacetic acid in water sprays, and from untreated plants. Each point represents the total yield of 55 plants. The bar graph (bottom, right) depicts the yield of marketable fruit for the picking season shown. 
in yield between treated and check plots after a long harvest season. This trend in yield is supported by the data from test 19 shown in table 13 . In test 19 the harvest period lasted 2 months and the crop was completely removed. The total yield from the treated plot was actually less than from the check. The chemical treatment might be considered to shift the harvest to an earlier part of the season but not to change the long-season yielding capacity of the plants. This shift in yield may be quite satisfactory to the freshmarket grower, whose primary interest is in early-season production, but it may be of no help to a grower harvesting over a long season.

There are two ways in which the chemical treatment may be responsible for the yield reduction following the period when the treated fruit was harvested : 1) the additional fruit-set reduces food reserves, which results in less vegetative growth and flower production; and 2) the growth regulators directly injure the plant. We have made no tests to separate these two responses, but both would increase with increasing concentration of growth substance in the carrier. The data from table 13, where plants were sprayed twice, indicate that the drop in yield shown for test 19 must be primarily from direct injury to the plant, since the $25 \mathrm{ppm}$ outyielded the 50 and $100 \mathrm{ppm}$ treatments for all pickings. This effect on yield has been observed in all of our tests where there has been a long harvest season. Wittwer et al. (1948) have observed a similar yield trend in field tests with the Victor variety, but in another test with Rutgers the treated plants continually outyielded the checks over a harvest period of about a month.

The effect of spraying plants more than once is illustrated by the yield data from test 19 given in table 13 and figure 5. In this test, plants of the Earliana variety were sprayed at the crown cluster stage with 3 concentrations of Na-4-CPA; 21 days later half of each plot was again sprayed with the same concentration. Separate yields for the 3 concentrations used-25, 50 , and $100 \mathrm{ppm}$-are given in table 13 , but for simplicity they are combined in figure 5, one line representing the plots sprayed once and another the plots sprayed twice. The peak yields which came about 50 days after treatment are evident for both sprayings in figure 5, top.

If table 13 is examined from the standpoint of early yield, it indicates that the plots in which the crown flower clusters were sprayed on April 19 yielded around a pound of fruit per plant prior to June 30 . This yield, though small, is important because it is early. The second spray, applied to the plants on May 10 when several flower clusters were open, further increased the harvests prior to July 2 , especially for the $25 \mathrm{ppm}$. The plants sprayed only once at the time the second spray was applied yielded well also, but the earlier yield prior to June 30 was missed.

Test 19 is unusual in that the plots sprayed with $25 \mathrm{ppm}$ yielded as well or better than the 50 and $100 \mathrm{ppm}$ plots. The higher concentrations were injurious, especially where the plants were sprayed twice. This disadvantage of double spraying is especially conspicuous if the total harvest through August 3 is considered. For the twice-sprayed plots, the plants treated with $25 \mathrm{ppm}$ of 4-CPA yielded about as well as the check, but the plants treated with $50 \mathrm{ppm}$ yielded only 70 per cent, and the $100 \mathrm{ppm}$ only 50 per cent as much as the check. 

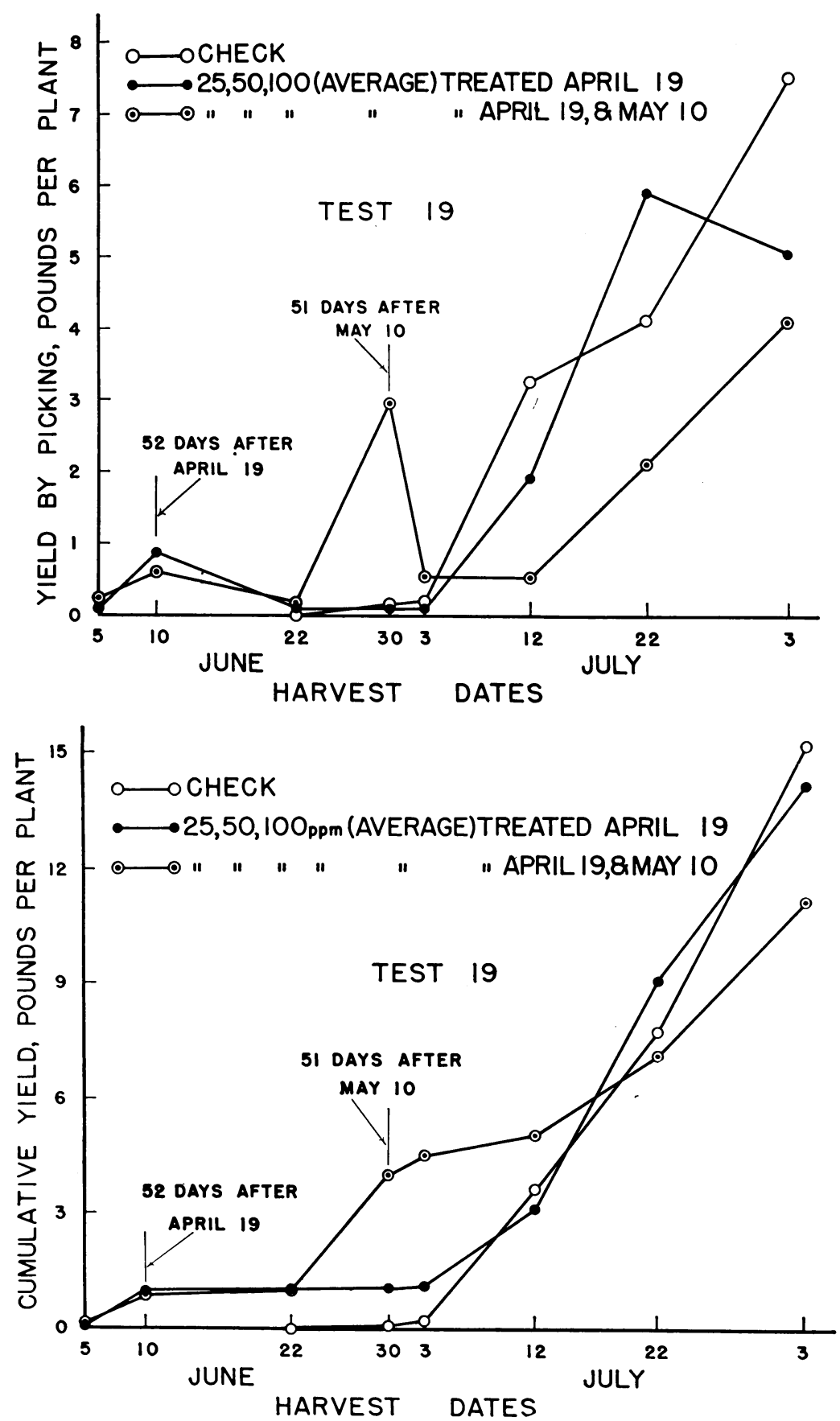

Fig. 5. Top, yield of fruit of the Earliana variety by pickings, and cumulative yield, bottom, from plants after one and two sprayings with Na-4-chlorophenoxyacetate, and from untreated plants. All treated plants sprayed on April 18 and one half of each plot again on May 10. For the treated plants, each value represents the average yield per plant from three spray concentrations $(25,50$, and $100 \mathrm{ppm})$. There were 40 to 60 plants per treatment. 
Under conditions where a $25 \mathrm{ppm}$ spray does not set fruit well, double spraying may show less benefit to early yield than it did in test 19. For example, in test 18, $25 \mathrm{ppm}$ was not very effective in setting fruit and double spraying with 25,50 , and $100 \mathrm{ppm}$ did not increase yields over single spray treatments.

TABLE 13

YIELDS OF FRUIT DURING SELECTED HARVEST PERIODS IN POUNDS PER PLANT AFTER ONE AND TWO SPRAYINGS WITH THREE CONCENTRATIONS OF Na-4-CPA*

\begin{tabular}{|c|c|c|c|c|}
\hline \multirow{2}{*}{ Treatments } & \multicolumn{3}{|c|}{ Yield by periods } & \multirow{2}{*}{$\begin{array}{c}\text { Total yield } \\
\begin{array}{c}\text { June 5 } \\
\text { to August } 3\end{array}\end{array}$} \\
\hline & $\begin{array}{c}\text { June } 5 \\
\text { to June } 22\end{array}$ & $\begin{array}{l}\text { June } 30 \\
\text { to July } 3\end{array}$ & $\begin{array}{c}\text { July } 12 \\
\text { to August } 3\end{array}$ & \\
\hline & $\begin{array}{c}\text { Pounds } \\
\text { per plant }\end{array}$ & $\begin{array}{c}\text { Pounds } \\
\text { per plant }\end{array}$ & $\begin{array}{c}\text { Pounds } \\
\text { per plant }\end{array}$ & $\begin{array}{c}\text { Pounds } \\
\text { per plant }\end{array}$ \\
\hline Untreated. . & 0.01 & 0.39 & 14.79 & 15.20 \\
\hline \multicolumn{5}{|l|}{ Sprayed once, April 19} \\
\hline Na-4-CPA, 25 ppm. & 0.97 & 0.50 & 12.84 & 13.97 \\
\hline $\mathrm{Na}-4-\mathrm{CPA}, 50 \mathrm{ppm}$. & 1.22 & 0.12 & 12.71 & 13.92 \\
\hline Na-4-CPA, 100 ppm..... & 0.81 & 0.11 & 12.91 & 13.79 \\
\hline \multicolumn{5}{|l|}{ Sprayed twice, April 19 and May 10} \\
\hline $\mathrm{Na}-4-\mathrm{CPA}, \quad 25 \mathrm{ppm} \ldots \ldots \ldots \ldots$ & 0.99 & 4.60 & 8.87 & 14.22 \\
\hline $\mathrm{Na}-4-\mathrm{CPA}, \quad 50 \mathrm{ppm} \ldots \ldots \ldots \ldots \ldots \ldots \ldots$ & 0.88 & 3.78 & 6.29 & 10.81 \\
\hline $\mathrm{Na}-4-\mathrm{CPA}, 100 \mathrm{ppm} \ldots \ldots \ldots \ldots \ldots \ldots \ldots$ & 0.59 & 2.41 & 4.49 & 7.46 \\
\hline \multicolumn{5}{|l|}{ Sprayed once, May 10} \\
\hline $\mathrm{Na}-4-\mathrm{CPA}, 25 \mathrm{ppm}$ & 0.00 & 5.27 & $\ldots \ldots$ & ..... \\
\hline \multicolumn{5}{|l|}{ Harvest period, days after treatment: } \\
\hline First spraying (Apr. 19) ........... & 47 to 64 & 65 to 75 & 76 to 106 & 47 to 106 \\
\hline Second spraying (May 10)... & 26 to 43 & 44 to 54 & 55 to 85 & 26 to 85 \\
\hline
\end{tabular}

* All treated plants sprayed on April 19, and one half of each plot again on May 10; each plot of 40 to 60 plants. Earliana variety. Test 19 of table 1.

These data indicate that double spraying may be desirable where early yield is of primary importance or where the marketing season is short. It may also be desirable where the period unfavorable to fruit-set is prolonged. However, spraying the same plant twice can be dangerous, especially if concentrations higher than $25 \mathrm{ppm}$ are used. Where $25 \mathrm{ppm}$ is not very effective in setting fruit-which seems to be true in some areas or under some conditions-a single spraying with a higher concentration at the general bloom stage may give greater yields than a double spraying. Also, where a long harvest season is desirable, double spraying should be done with caution. In some cases spraying separate parts of a field at different times may offer a better solution. 


\section{SUMMARY AND CONCLUSIONS}

This paper describes 29 experiments on setting fruit with growth-regulating substances on field-grown tomatoes. These tests were conducted during 1945 to 1947 in 11 counties of California.

The chemicals used were $\beta$-naphthoxyacetic, 4-chlorophenoxyacetic, and 2,4-dichlorophenoxyacetic acids. These chemicals were applied in 3 types of carriers : water sprays without spreaders, dusts, and aerosols.

Growth-regulating substances were effective in increasing the set or the early yield of fruit in all but 3 tests. All combinations of chemicals and carriers used were effective in setting fruit. All 5 tomato varieties on which tests were conducted showed responses to growth substances.

Plant injury was severe when the whole plant was treated, regardless of the material used or the carrier. To keep this injury to a minimum it was necessary to confine the chemical as much as possible to the flower clusters. The drifting of dusts and aerosols made them less desirable carriers than water sprays.

Fruit shape was slightly altered but seldom to an objectionable degree. Sunburning of fruit may be increased if foliage is severely injured. The proportion of rough fruits in the early crop may be raised by setting fasciated flowers which usually drop if not treated.

Blossom-end rot and puffiness were not serious defects in any tests. The green color of the gelatinous pulp is more persistent after treatment. Defects other than fruit shape do not appear to be directly caused by chemical treatment, but where they occur naturally they may be accentuated.

Flowers from the stage of large buds to those with drying petals may be set by growth substances.

Fruit size was consistently increased by growth-substance treatments. In some tests a considerable part of the increased early yield resulted from larger size of fruit. For 4-CPA water sprays, the largest fruits were produced by $25 \mathrm{ppm}$ and the fruit size decreased with higher concentrations. This inverse relationship between fruit size and concentration did not hold for other growth substances or types of carriers.

In our tests, $50 \mathrm{ppm}$ of 4-CPA gave the most consistent results for a single spraying. However, $25 \mathrm{ppm}$ was sometimes equally as effective in increasing early yields and had the advantage of being less injurious. In Tulare County the $100 \mathrm{ppm}$ concentration usually gave the best results. From the standpoint of plant injury, the minimum concentration that will give satisfactory fruitset is the most desirable.

Tomatoes set by a single growth-substance treatment usually ripened over a period of about 2 weeks. The interval from time of treatment to peak harvest ranged from 49 to 58 days for Earliana and 56 to 62 days for Pearson.

For a harvest season ending 1 or 2 weeks after the day of peak yield, the treated plots may be markedly superior to the check in cumulative yield. As the harvest season is extended, the cumulative yield from the check plots approaches the yield of the treated plots. The growth-substance treatment may be said to shift the yield of fruit to an earlier period in the season rather than to increase the yielding capacity of the plants. 
Spraying a plot more than once is hazardous, especially at concentrations above $25 \mathrm{ppm}$ of 4-CPA. Where early yield is especially important, or where the period unfavorable to setting is prolonged, spraying plants a second time might be warranted. Spraying separate parts of a field at different times may offer a better solution.

Knowledge of the possibilities, functioning, and hazards of growth substances is imperative if a grower is to develop a sound program with their use. A single test in a given area may not accurately reflect what can be expected in other years or districts. Seasonal variations in market conditions add to the difficulty in predicting their role. They can be harmful, particularly if improperly used in timing or in methods of application. Accordingly, growers are advised to proceed cautiously for the present, and to conduct moderatesized trials over several seasons before drawing final conclusions on the value of growth substances.

\section{ACKNOWLEDGMENTS}

Farm advisors Henry Washburn, Clyde Barnum, Al Gotelli, B. J. Hall, Dave Holmberg, Sheldon Jackson, Henry Longfellow, R. D. McCallum, H. W. Schwalm, J. E. Swift, and Ralph Worrell assisted in conducting these tests. Completion of many of the tests depended entirely on their help. The growers on whose farms the tests were conducted contributed freely of their time in the collection of yield data. We appreciate their fine coöperation. 


\section{LITERATURE CITED}

Anonymous.

1948. Tomato yields increased by field application of hormones. Market Growers Jour. $77(5): 8,46,49$.

Gustafson, Felix G.

1940. Parthenocarpic and normal fruits compared as to percentage of setting and size. Bot. Gaz. 102:280-86.

1942. $\beta$-Naphthoxyacetic acid as an inductor of parthenocarpy in tomatoes. Amer. Soc. Hort. Sci. Proc. 40:387-89.

Hamner, Charles L., Harold A. Schomer, and PaUl C. Marth.

1944. Application of growth-regulating substance in aerosol form, with special reference to fruit-set in tomato. Bot. Gaz. 106:108-23.

HowletT, Freeman S.

1939. Experiments concerning the practicability of certain chemicals as a means of inducing fruit setting in the tomato. Amer. Soc. Hort. Sci. Proc. 37:886-90.

1941. Use of chemicals to stimulate fruitfulness in tomatoes. Vegetable Growers Association of America Inc., Ann. Rept. 1941:203-14.

1943. Growth-promoting chemicals improve greenhouse tomato production. Ohio Exp. Sta. Bimonthly Bul. 28(220):17-27.

Howlett, Freeman S., and Paul Marth.

1946. Aerosol applications of growth-regulating substances to the greenhouse tomato. Amer. Soc. Hort. Sci. Proc. 48:458-74.

JANES, BYRON E.

1941. Some chemical differences between artificially produced parthenocarpic fruits and normal seeded fruits of tomato. Amer. Jour. Bot. 28:639-46.

Mitchell, JoHN W.

1947. Plant growth regulators. Science in farming. U.S.D.A. Yearbook of Agriculture, 1943-1947:256-66.

Mitchell, JohN W., and Muriel R. Whitehead.

1942. Effects of vaporous naphthoxyacetic acid on development of tomato fruits, with special reference to their vitamin C content. Bot. Gaz. 104:362-65.

Murneek, A. E., S. H. WitTwer, and D. D. Hemphili.

1944. Supplementary "hormone" sprays for greenhouse-grown tomatoes. Amer. Soc. Hort. Sci. Proc. 45:371-81.

RoBerts, R. H., and B. Esther StrUCKMEYer.

1944. The use of sprays to set greenhouse tomatoes. Amer. Soc. Hort. Sci. Proc. 44:417-27.

SCHROEDER, R. A.

1937. Application of plant hormones to tomato ovaries. Amer. Soc. Hort. Sci. Proc. 35: 537-38.

Strong, Miriam C.

1941. The effect of various growth-promoting chemicals on the production of tomato fruits in the greenhouse. Michigan Agr. Exp. Sta. Quart. Bul. 24(1):56-64.

1944. Improvement of greenhouse tomato production by use of vaporous beta naphthoxyacetic acid. Michigan Agr. Exp. Sta. Quart. Bul. 27(2):225-36.

1946. Use of 2,4-dichlorophenoxyacetic acid for the improvement of greenhouse tomato production. Michigan Agr. Exp. Sta. Quart. Bul. 28(3):216-25.

WENT, F. W.

1944. Plant growth under controlled conditions. II. Thermoperiodicity in growth and fruiting of the tomato. Amer. Jour. Bot. 31:135-50.

WitTwer, S. H., H. Stallworth, and M. J. Howell.

1948. The value of a "hormone" spray for overcoming delayed fruit set and increasing yields of outdoor tomatoes. Amer. Soc. Hort. Sci. Proc. 51:371-80. 
Zimmerman, P. W., and A. E. Hitchcock.

1942. Substituted phenoxy and benzoic acid growth substances and the relation of structure to physiological activity. Boyce Thompson Inst. Contrib. 12:321-43.

1944. Substances effective for increasing fruit set and inducing seedless tomatoes. Amer. Soc. Hort. Sei. Proc. 45:353-61.

Zimmerman, P. W., A. E. Hitchcock, and E. K. Harvill.

1944. Xylenoxy growth substances. Boyce Thompson Inst. Contrib. 13:273-80. 

The journal Hilgardia is published at irregular intervals, in volumes of about 600 pages. The number of issues per volume varies.

Subscriptions are not sold. The periodical is sent as published only to libraries or to institutions in foreign countries having publications to offer in exchange.

You may obtain a single copy of any issue free, as long as the supply lasts; please request by volume and issue number from:

Publications Office

College of Agriculture

Berkeley 4, California

The limit to nonresidents of California is 10 separate issues on a single order. A list of the issues still available will be sent on request. 
six $\sqrt{2}+x^{2}+2$

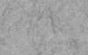

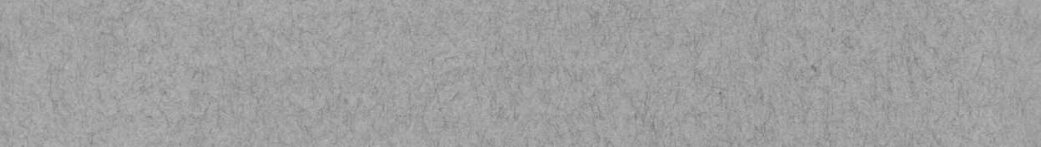

$$
\begin{aligned}
& \text { (12) } \\
& \text { 1.0.0. }
\end{aligned}
$$

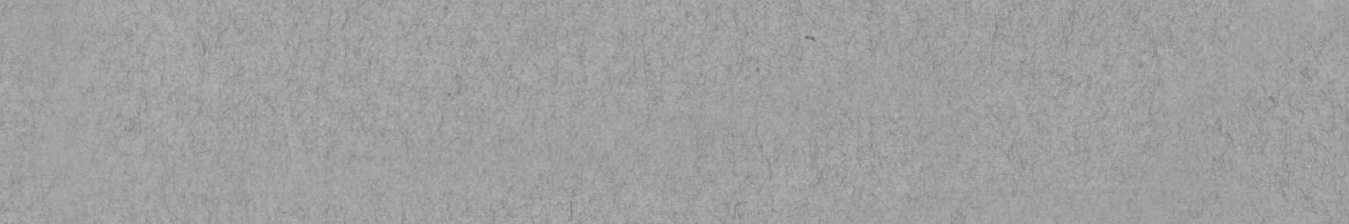

